\title{
General Approach for Template-Directed Synthesis of Macroheterocycles by Ring-Closing Metathesis (RCM)
}

\author{
Alexey V. Chuchuryukin, ${ }^{a}$ Preston A. Chase, ${ }^{a}$ Harm P. Dijkstra, ${ }^{a}$ \\ Bart M. J. M. Suijkerbuijk, ${ }^{a}$ Allison M. Mills, ${ }^{b}$ Anthony L. Spek, ${ }^{b, c}$ \\ Gerard P. M. van Klink, ${ }^{\mathrm{a}}$ Gerard van Koten ${ }^{\mathrm{a}, *}$ \\ a Debye Institute, Department of Metal-Mediated Synthesis, Utrecht University, Padualaan 8, $3584 \mathrm{CH}$ Utrecht, \\ The Netherlands \\ Phone: (+31)-30-253-3120, fax: (+31)-30-252-3615, e-mail: g.vankoten@chem.uu.nl \\ b Bijvoet Center for Biomolecular Research, Department of Crystal and Structural Chemistry, Utrecht University, \\ Padualaan 8, 3584 CH Utrecht, The Netherlands \\ c Correspondence pertaining to crystallographic studies should be addressed to this author \\ E-mail: a.l.spek@chem.uu.nl
}

Received: September 6, 2004; Accepted: December 3, 2004

Dedicated to Prof. Dr. Richard Schrock on the occasion of his $60^{\text {th }}$ birthday and in recognition of his highly appreciated contribution to chemistry in general and his pioneering studies on ofefin metathesis in particular.

Abstract: A general method to prepare macrohetero-
cycles is reported in which a rigid symmetric platinat-
ed tris-pincer tricationic complex (3) is used as a tem-
plate. The system uses bisolefin functionalized pyri-
dine ligands (1, 2) which selectively bind to the three
platinum centers of the template resulting in pre-or-
ganization of the olefinic tails. By subjecting these
pre-organized complexes (4) to olefin metathesis re-
action conditions, the olefinic tails were interconnect-
ed affording several macroheterocycles of different
compositions and sizes. Various pyridines with differ-
ent substitution patterns (2,6- and 3,5-disubstituted)
and different olefinic tails (aliphatic, polyether, and
styryl) were synthesized and used in the cyclization
reactions, showing the diversity of this method. It
was found that only the use of 2,6-disubstituted pyri-
dines resulted in the formation of the desired macro-
cycles while 3,5-difunctionalized pyridines gave only
pyridinophane formation. Furthermore, the length

\section{Introduction}

Macroheterocyclic compounds are widely used as ligands for complexation to single metal cations and small polar organic molecules (e.g., urea). ${ }^{[1]}$ Additionally, Stoddart and co-workers have expanded the scope of the crown-ether family in the development of, e.g., molecular shuttles, ${ }^{[2]}$ switches, ${ }^{[3]}$ and logic gates ${ }^{[4]}$ using catenane and rotaxane chemistry. ${ }^{[5]}$ Nevertheless, only a few examples are described in the literature where macroheterocycles were used as ligands for complexation to rigid polymetallic complexes. ${ }^{[6]}$ Recently, we reported of the olefinic tails needs to be at least eleven atoms $(\mathrm{C}$ or $\mathrm{O})$ in order to suppress oligomerization in favor of macrocycle formation. Yields of up to $70 \%$ of the macrocycles were obtained using the first-generation $\left[\mathrm{Cl}_{2}\left(\mathrm{Cy}_{3} \mathrm{P}\right)_{2} \mathrm{Ru}=\mathrm{CHPh}\right]$ or second-generation $\left[\mathrm{Cl}_{2}\left(\mathrm{Cy}_{3} \mathrm{P}\right)(\mathrm{IMes}) \mathrm{Ru}=\mathrm{CHPh}\right]$ Grubbs' catalysts. Reactions of the platinated pincer pyridines with Schrock Mo-based metathesis catalysts results in exclusive olefin isomerization and no productive metathesis. The generated macrocycles (hosts) could effectively be separated from the template by addition of aqueous sodium chloride and reattached to the (recycled) template (guest). The X-ray structure determination of host-guest complex $\mathbf{1 0}$ is the definite proof for this reattachment and the perfect cyclic structure of the macrocycle.

Keywords: macrocyclic ligands; metathesis; $\mathrm{N}$ ligands; platinum; ring-closing metathesis; synthetic design the synthesis of macromolecular tri- and hexametallic ECE-pincer complexes (A-C, Figure 1) and investigated their use as recyclable homogeneous catalysts in a nanofiltration membrane reactor. ${ }^{[7]}$ Two interesting features of these molecules are their shape-persistent backbones and their highly symmetric geometries, two very important features for a polynuclear macromolecular template in the controlled synthesis of macrocycles. We anticipated that coordinating bifunctional ligands to the metal centers of these complexes should result in the pre-organization of the functional groups in such a way that they can easily be interconnected to 


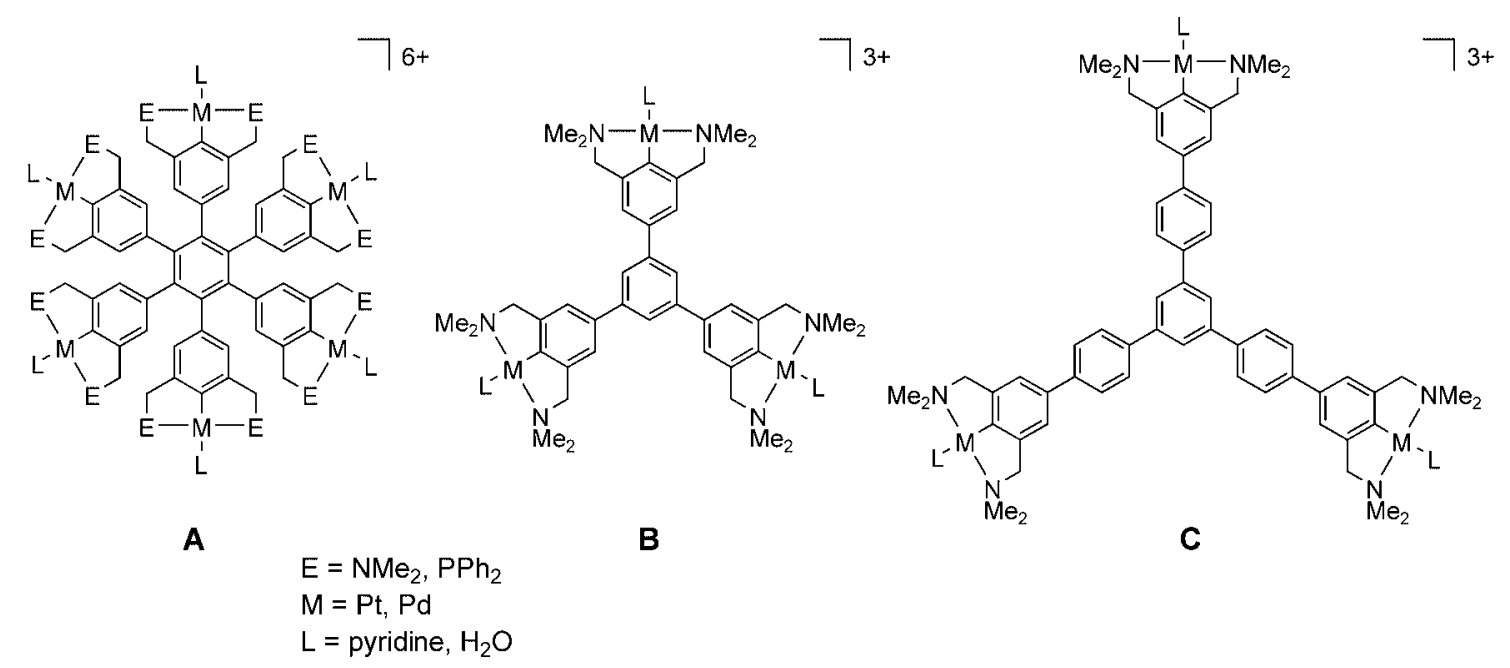

Figure 1. Symmetric shape-persistent tri- and hexametallic pincer complexes.

form macrocycles. In this approach the final ring-closing reaction (various side-reactions are anticipated) as well as the nature of the metal-to-ligand coordination bond (needs to be sufficiently strong to suppress ligand dissociation) are of crucial importance.

Olefin metathesis has developed into one of the most important synthetic methods for the selective generation of medium to large cyclic systems. ${ }^{[8]}$ A few reports in literature describe the synthesis of macroheterocycles by metathesis of olefin-substituted ligands in the coordination sphere of organometallic complexes. Most of these procedures use monometallic complexes as the templates. ${ }^{[9]}$ Also the application of metathesis in the synthesis of catenanes, ${ }^{[10]}$ molecular knots ${ }^{[11]}$ and molecular wires, insulated with a double helix of alkene chains have been reported, in which a metal ion was used as the template to ensure the desired geometry. ${ }^{[12]}$ Recently, we reported a model study in which we applied monometallic ECE-pincer complexes $(E=N, S$, metal $=$ palladium, platinum) coordinated to bisolefin functionalized pyridines in ring-closing metathesis (RCM) reactions. ${ }^{[13]}$ This study was performed to determine the optimal reaction conditions for the application of metalated multi-ECE-complexes (see Figure 1) as templates in the synthesis of macrocycles. Pyridine ligands were chosen because they form stable coordination complexes with many palladium and platinum complexes and they can also be rather easily functionalized. It was found that the NCN-pincer platinum pyridine complexes were kinetically the most stable. In addition, the pyridine ligated NCN-Pt moiety was found to be the least active catalyst in a competitive prototropic isomerization of the olefinic double bonds (a process known to be catalyzed by a variety of transition metals ${ }^{[14]}$ ) to form internal double bonds (which are considerably less active in metathesis), making this moiety the most attractive for the templated synthesis of polypyridine macrocycles.
Earlier we communicated the preliminary results on the synthesis of tris(pyridyl)alkyl heteromacrocycles using platinated tri-NCN-pincer complex B (Figure 1) as a template. ${ }^{[15]}$ Here we report a full account of the use of this shape-persistent tri-metallic template for the general synthesis of macroheterocycles of several compositions.

\section{Results and Discussion}

As the starting materials for the template-directed macrocycle synthesis, a number of 2,6-bisolefin substituted pyridines $(\mathbf{1 a}-\mathbf{g})$ and a 3,5-bisolefin substituted pyridine (2a) were used (see Scheme 1). This selection enabled us to study the influence of the length of the olefin-bearing chains as well as their positions on the pyridine rings (3,5- or 2,6-substitution) on the selectivity and the yield of the ring-closing reactions.

The synthesis of the disubstituted pyridine ligands is outlined in Scheme 1. Treatment of 2,6-dibromopyridine with the in situ prepared sodium salts of the appropriate olefinic alcohols in dry DMF gave 2,6-disubstituted pyridines 1a - e in $82-97 \%$ yield [Scheme 1, Equation (1)]. Pyridine derivatives $\mathbf{1 f}$ and $\mathbf{g}$ were obtained in a two-step sequence; 2,6-pyridinedimethanol was first reacted with thionyl chloride and subsequent treatment of the resulting 2,6-bis(chloromethyl)pyridinium chloride with three equivalents of the in situ prepared sodium salts of 9-decen-1-ol (1f) or 5-hexen-1-ol (1g) yielded the corresponding pyridines $\mathbf{1 f}$ and $\mathbf{1 g}$ both in $97 \%$ yield [Scheme 1, Equation (2)]. Finally, treatment of 3,5-pyridinedicarboxylic acid with thionyl chloride and subsequent reaction of 2,6-pyridinedicarbonyl dichloride with 9-decen-1-ol resulted, after a basic work-up, in the formation of $\mathbf{2 a}$ in $92 \%$ yield [Scheme 1, Equation (3)].

The synthesis of the trispyridine-template complexes is shown in Scheme 2. In all cases, the template precur- 


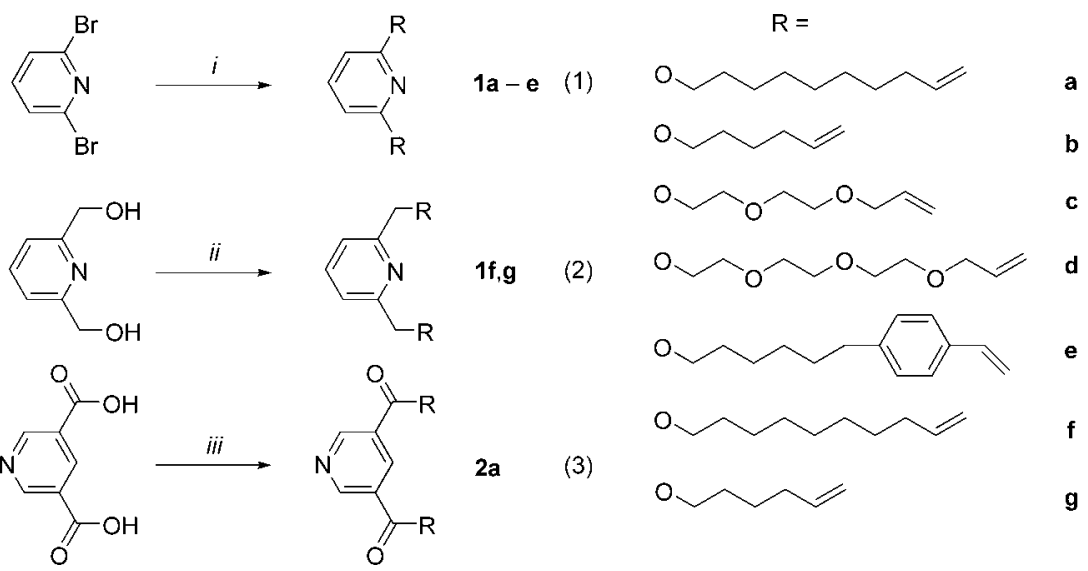

Scheme 1. Synthesis of bisolefin substituted pyridines. i) Appropriate sodium alkoxide, DMF, $\left.95^{\circ} \mathrm{C}, 16 \mathrm{~h} . \mathrm{ii}\right) \mathrm{SOCl}_{2}, \mathrm{CH}_{2} \mathrm{Cl}_{2}$, $\mathrm{RT}, 16 \mathrm{~h}$ followed by sodium 9-decen-1-olate (1f) or sodium 5-hexen-1-olate (1g), THF, reflux, $4 \mathrm{~h}$. iii) $\mathrm{SOCl}_{2}, \mathrm{reflux}, 16 \mathrm{~h}$ followed by 9-decen-1-ol, $\mathrm{CH}_{2} \mathrm{Cl}_{2}$, reflux, $3 \mathrm{~h}$.
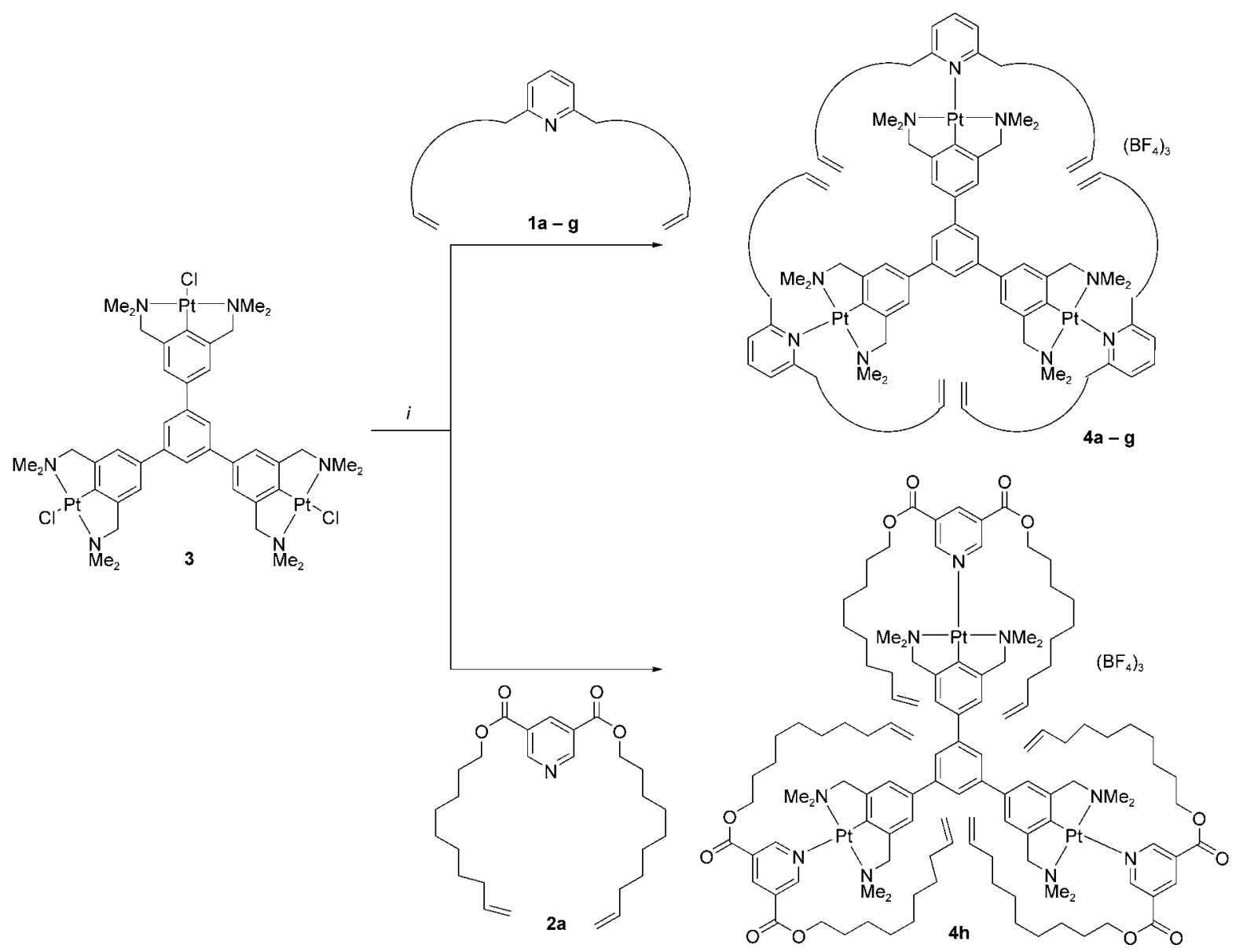

Scheme 2. Synthesis of trispyridine-template complexes. i) $\mathrm{AgBF}_{4}, \mathrm{CH}_{2} \mathrm{Cl}_{2}, \mathrm{RT}, 16 \mathrm{~h}$.

sor $\mathbf{3}^{[7 a]}$ was reacted in dichloromethane with three equivalents of the appropriate pyridine $(\mathbf{1 a}-\mathbf{g}$ or $\mathbf{2 a})$ in the presence of suspended silver tetrafluoroborate, giving the cationic coordination complexes $4 \mathbf{a}-\mathbf{h}$, respectively, in quantitative yields. In all cases, a prolonged reaction time $(16 \mathrm{~h})$ was necessary due to the poor solubil- ity of silver tetrafluoroborate in dichloromethane. Cationic complexes $\mathbf{4 a}, \mathbf{4 b}$, and $\mathbf{4 e}-\mathbf{h}$ were obtained pure after removal of insoluble silver chloride and used immediately in the RCM reactions. In the case of pyridine derivatives $\mathbf{1 c}$ and $\mathbf{1 d}$, however, significant amounts of silver salts $(\sim 10 \mathrm{~mol} \%$ of the total amount of silver 
Table 1. Conditions and yields of RCM reactions.

\begin{tabular}{|c|c|c|c|c|}
\hline Starting material & Catalyst [mol \%/pyridine] & Time $[\mathrm{h}]$ & Product & Yield [\% 9 \\
\hline $4 a$ & $\mathrm{Cl}_{2}\left(\mathrm{Cy}_{3} \mathrm{P}\right)_{2} \mathrm{Ru}=\mathrm{CHPh}(5)$ & 16 & 6a & 67 \\
\hline $4 \mathbf{b}$ & $\mathrm{Cl}_{2}\left(\mathrm{Cy}_{3} \mathrm{P}\right)_{2} \mathrm{Ru}=\mathrm{CHPh}(5-10)$ & $16-74$ & $\mathbf{6 b}$ & 0 \\
\hline $4 c$ & $\mathrm{Cl}_{2}\left(\mathrm{Cy}_{3} \mathrm{P}\right)_{2} \mathrm{Ru}=\mathrm{CHPh}(5-10)$ & $16-74$ & 6c & 0 \\
\hline 4d & $\mathrm{Cl}_{2}\left(\mathrm{Cy}_{3} \mathrm{P}\right)_{2} \mathrm{Ru}=\mathrm{CHPh}(5)$ & 16 & 6d & 41 \\
\hline $4 e$ & $\mathrm{Cl}_{2}\left(\mathrm{Cy}_{3} \mathrm{P}\right)(\mathrm{IMes}) \mathrm{Ru}=\mathrm{CHPh}(15)$ & 48 & $6 \mathbf{e}$ & 60 \\
\hline 4f & $\mathrm{Cl}_{2}\left(\mathrm{Cy}_{3} \mathrm{P}\right)_{2} \mathrm{Ru}=\mathrm{CHPh}$ & 16 & 6f & 44 \\
\hline $4 f$ & $\mathrm{Cl}_{2}\left(\mathrm{Cy}_{3} \mathrm{P}\right)(\mathrm{IMes}) \mathrm{Ru}=\mathrm{CHPh}$ & 16 & 6f & 20 \\
\hline $4 \mathrm{~g}$ & $\mathrm{Cl}_{2}\left(\mathrm{Cy}_{3} \mathrm{P}\right)_{2} \mathrm{Ru}=\mathrm{CHPh}(5-10)$ & $16-74$ & $6 \mathrm{~g}$ & 0 \\
\hline $4 \mathrm{~h}$ & $\mathrm{Cl}_{2}\left(\mathrm{Cy}_{3} \mathrm{P}\right)_{2} \mathrm{Ru}=\mathrm{CHPh}(12.5)$ & 48 & 8 & 70 \\
\hline $4 a$ & Schrock catalyst $\mathbf{1 1}$ & 16 & 12 & 67 \\
\hline
\end{tabular}

tetrafluoroborate used) were still present in the final solutions of the corresponding complexes $\mathbf{4 c}$ and $\mathbf{4 d}$ after removal of insoluble silver chloride by filtration. This is probably a result of partial solubilization of silver salts by the crown-ether like compounds $\mathbf{1 c}$ and $\mathbf{1 d}$. It was observed that complexes containing the dissolved silver salts did not undergo ring-closing metathesis possibly due to catalyst deactivation. Therefore, the residual dissolved silver salts were removed by passing small amounts of hydrogen sulfide through the reaction mixture prior to metathesis. Large excess of hydrogen sulfide should be avoided since it causes reversible breakage of the platinum-N(pyridine) bond of the cationic complexes $\mathbf{4 c}$ and $\mathbf{4 d}$, resulting in mixtures of different pincer-ligand complexes ( $\mathrm{Pt}-\mathrm{N}$ and $\mathrm{Pt}-\mathrm{S}$ complexes). The small excess of hydrogen sulfide was removed from the reaction mixture by heating the reaction mixture to reflux under a nitrogen atmosphere followed by removal of silver sulfide by filtration prior to metathesis.

Cationic complexes $\mathbf{4 a}-\mathbf{h}$ were applied in olefin metathesis in the presence of first or second-generation Grubbs' catalysts (5-15 mol \% per pyridine ligand) (Scheme 3). In addition, metathesis with 4a was attempted with Schrock Mo-based catalysts (vide infra). The conditions for the RCM reactions and the yields of the obtained macrocycles are summarized in Table 1. The olefin metathesis reactions were performed under high dilution $\left(\sim 10^{-3} \mathrm{M}\right)$ to suppress intermolecular olefin metathesis polymerization. For analysis purposes, all pyridine fragments were detached from the template after metathesis by reacting the resulting platinum pyridine complexes with an aqueous sodium chloride solution, affording free metathesis products and the neutral template precursor 3 . The pyridine products could be completely separated from $\mathbf{3}$ by extraction with hexanes In fact, as $\mathbf{3}$ is completely insoluble in hexanes, pure $\mathbf{3}$ was quantitatively recovered and could be reused in subsequent experiments.

Trispyridine-template complexes $4 \mathbf{a}, \mathbf{4 d}$ and $4 \mathbf{f}$ were converted into their corresponding trispyridine macrocycles 5a, 5d and 5f using first-generation Grubbs' catalyst $\left[\mathrm{Cl}_{2}\left(\mathrm{PCy}_{3}\right)_{2} \mathrm{Ru}=\mathrm{CHPh}\right](5 \mathrm{~mol} \%$ per pyridine li- gand) (Scheme 3). After detachment from the template by aqueous sodium chloride, the macroheterocycles $\mathbf{6 a}$, 6d and 6f were obtained as mixtures of cis/trans trisolefinic heteromacrocycles. The total yields of macroheterocycles $6 \mathbf{a}, \mathbf{6 d}$ and $\mathbf{6 f}$, after isolation by preparative thin-layer chromatography (TLC), varied from 41 to $67 \%$ (Table 1). The best yield was obtained with $4 \mathbf{a}$ (forming 6a) in which the olefinic tail contains 11 atoms, whereas complexes $\mathbf{4 d}$ and $\mathbf{4 f}$ bearing pyridines with olefinic tails of 13 and 12 atoms, respectively, gave somewhat lower yields of 41 and $44 \%$ (which still equates to $>74 \%$ yield per double bond). In the case of pyridine substrates 1b, 1c and 1g (complexes 4b, 4c and 4g, Scheme 3) with olefinic chains bearing less than 11 atoms $(\mathrm{O}, \mathrm{C})$, no trispyridine macrocycles were observed on applying the same metathesis reaction conditions. Also increasing the amount of metathesis catalyst (up to $15 \mathrm{~mol} \%$ ) did not result in the formation of macrocyclic metathesis products, instead predominantly linear oligomers were found. These results show that the length of the olefinic tail plays an important role in this research with the optimum lying at 11 atoms $(\mathrm{C}$, O) for this particular template. A similar pyridinophane cyclization reaction was recently reported by Fürstner. ${ }^{[16]}$

Template-directed RCM of the less active bis-styrene derivative $4 \mathbf{e}$, on the other hand, was only possible in the presence of large amounts (15 mol \%) of the more active second-generation Grubbs' catalyst, $\left[\mathrm{Cl}_{2}\left(\mathrm{PCy}_{3}\right)\right.$ (IMes)$\mathrm{Ru}=\mathrm{CHPh}][\mathrm{IMes}=1,3$-bis(2,4,6-trimethylphenyl)-4,5dihydro-imidazol-2-ylidene]. In fact, applying the firstgeneration Grubbs' catalyst in this reaction resulted in no metathesis at all. The resulting macroheterocycle 6e was originally isolated as the pure trans-trisolefin, however, it was found to undergo slow cis/trans-isomerization in solution when exposed to daylight.

Surprisingly, changing the substitution pattern from 2,6- to 3,5-diolefin functionalized pyridines, resulted solely in pyridinophane RCM. Thus subjecting $4 \mathbf{h}$ to the RCM conditions gave only monopyridinyl macrocycle (pyridinophane) 8 in 70\% yield (Scheme 3 ); no indication of a trispyridinyl macrocycle was observed even though the length of the olefinic chains (12 atoms) was 


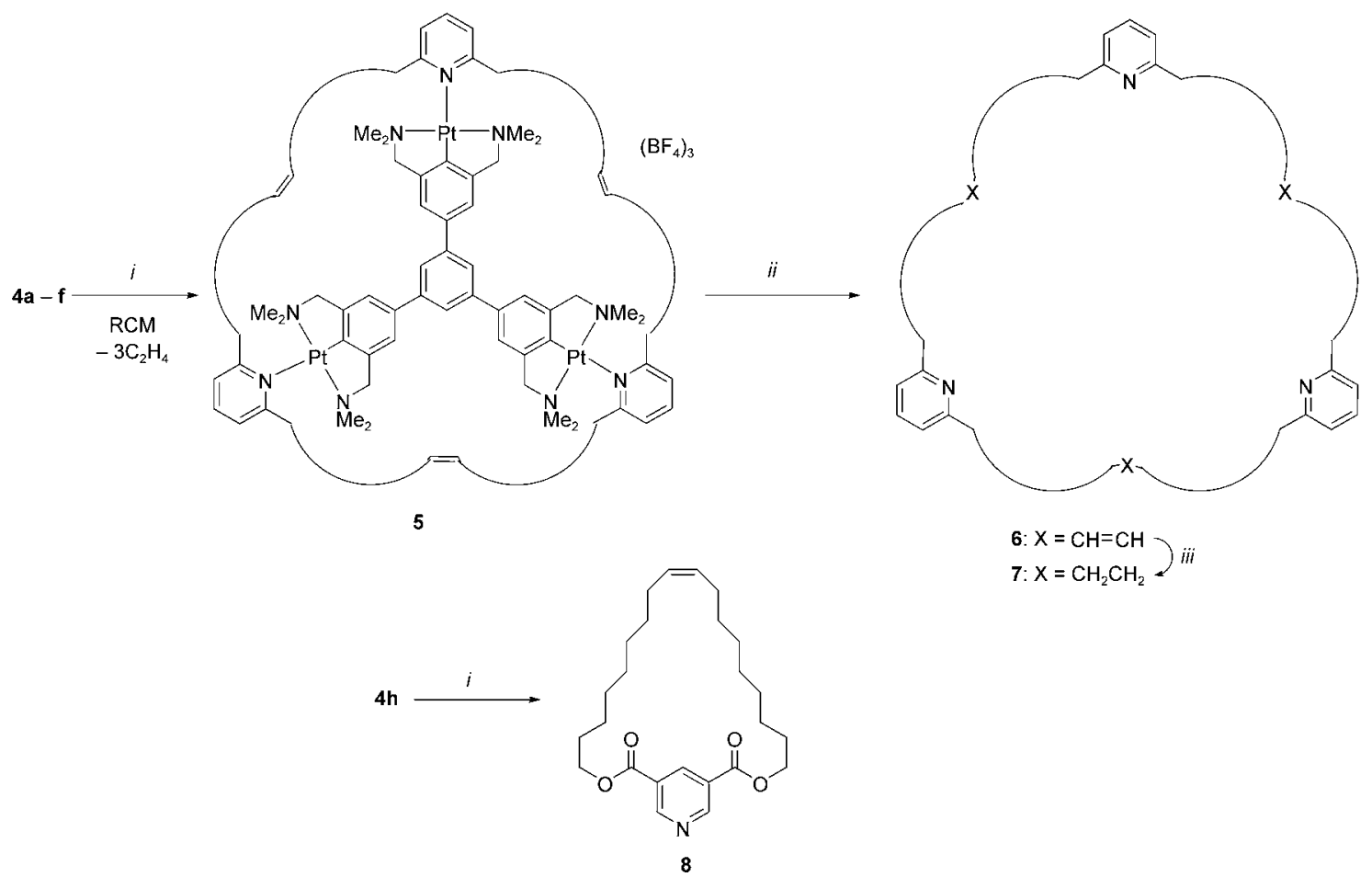

Scheme 3. RCM with template-bound bisolefin-substituted pyridines. i) [Ru] catalyst 5-15 mol \%, $\mathrm{CH}_{2} \mathrm{Cl}_{2}, \mathrm{reflux}$. ii) $\mathrm{NaCl}$, $\mathrm{H}_{2} \mathrm{O} / \mathrm{CH}_{2} \mathrm{Cl}_{2}$, RT, 20 h. iii) $\mathrm{H}_{2}, \mathrm{Pd} / \mathrm{C}$, RT, various solvents.

anticipated to be sufficient for trispyridinyl macrocycle formation. Apparently, in case of 3,5-disubstituted pyridines, the two olefinic tails of one pyridine ligand can easily reach each other since there is hardly any steric hindrance of the pyridine ring, making pyridinophane RCM preferable. ${ }^{[13]}$ In the case of 2,6-disubstituted pyridines this undesired process is impeded due to steric hindrance of the pyridine ring and the NCN-Pt pincer; an intramolecular RCM (to give a pyridinophane) would have to take place via a back-flip conformation, which is highly unfavorable.

In the synthesis of $\mathbf{6 a}, 6 \mathbf{d}$ and $\mathbf{6 f}$, not only the desired macrocycles were obtained but also linear oligomers were formed as minor side-products. In an attempt to increase the reaction rate and the selectivity of the RCM reaction and to decrease the amount of catalyst, the more reactive second-generation Grubbs' catalyst, $\left[\mathrm{Cl}_{2}\left(\mathrm{PCy}_{3}\right)(\mathrm{IMes}) \mathrm{Ru}=\mathrm{CHPh}\right]$, was used in the metathesis reaction of $4 \mathbf{f}$ (as a model reaction). Unfortunately, this led to a dramatic decrease in yield of macrocycle 6f $(20 \%$, Table 1$)$, while large amounts of oligomers were formed. These findings point to the occurrence of secondary cross and ring-opening metathesis polymerization (ROMP) reactions. Only in the case of styrene derivative 4e did the second generation Grubbs' catalyst give a satisfactory result (vide supra). Apparently, due to the less-active nature of the double bonds of the styrene moiety and the higher stability of the resulting stilbenoid double bonds, cross-metathesis and ROMP are prevented, affording $\mathbf{6 e}$ in high selectivity. Longer reaction times could be applied in this case since the styrene double bond does not suffer from the transition metalcatalyzed olefin isomerization reaction for obvious reasons.

As macrocycles 6 were formed as mixtures of cis/transtrisolefinic heteromacrocycles, hydrogenation of the double bonds in 6 using $\mathrm{H}_{2}$ and $\mathrm{Pd} / \mathrm{C}$ in $\mathrm{CH}_{2} \mathrm{Cl}_{2}$ was performed to facilitate analysis, affording the corresponding saturated macrocycles 7 (Scheme 3 ). In the case of 7f, some hydrogenolysis of the benzylic ether bonds was observed as a side reaction. ${ }^{[17]}$ Furthermore, it should be noted that according to mass spectrometry the product mixtures of the saturated compounds $7 \mathbf{a}$ and $7 f$ contained traces of macrocycles $(<5 \%)$ having one $\mathrm{CH}_{2}$ group less then the expected macrocycles. These macrocycles were most likely formed through cross metathesis of an $\alpha$-olefinic substituent (external double bond) with a $\beta$-olefinic one (internal double bond), the latter being formed by a metal-catalyzed prototropic isomerization reaction (vide supra). ${ }^{[14]}$ Unfortunately, it was not possible to separate these macrocycles from the desired products $7 \mathbf{a}$ and $\mathbf{7 f}$ by preparative TLC.

The macrocycles 7a, 7d and 7f, which are very flexible and not preorganized (e.g., by conformational preferences in the connecting alkanediyl chains), were further studied as hosts for the highly preorganized macromolecular trimetallic guest $\mathbf{3}$ (Scheme 4). The reactions of macrocycles 7a, 7d and $7 \mathbf{f}$ with $\mathbf{3}$ in dichloromethane in 

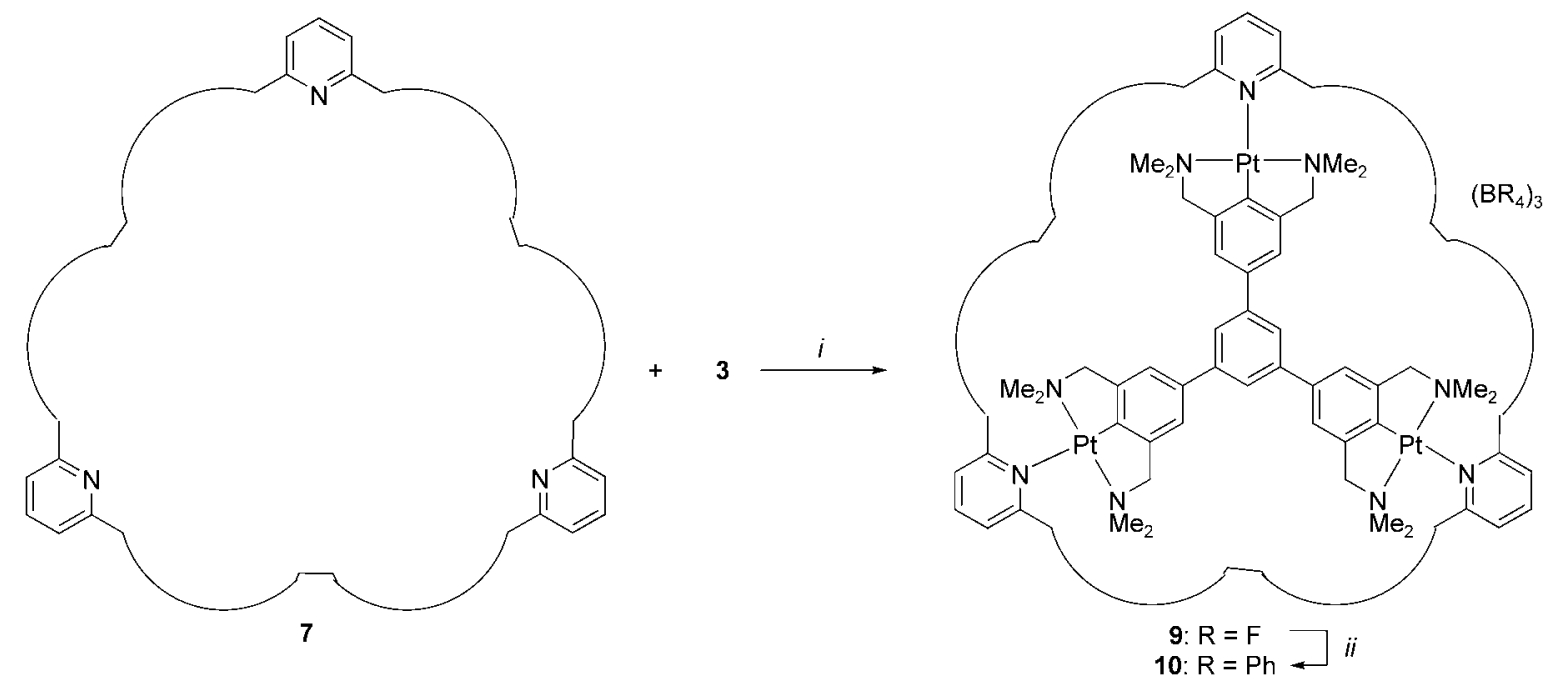

Scheme 4. Host-guest chemistry with macrocycles. i) $\mathrm{AgBF}_{4}, \mathrm{CH}_{2} \mathrm{Cl}_{2}, \mathrm{RT}, 16 \mathrm{~h}$ followed by work-up with acetone. ii) $\mathrm{NaBPh}_{4}$, acetone, RT, $1 \mathrm{~h}$.

the presence of silver tetrafluoroborate gave - after work-up with acetone - the corresponding complexes 9a, 9d and 9f in almost quantitative yield (95-98\%). Characterization of host-guest complexes 9 comprised NMR spectroscopy, elemental analysis and electrospray mass spectrometry. The mass and isotopic patterns in the experimental spectra were identical to that in the calculated spectra for the tricationic complexes 9. In spite of all the convincing evidence for the formation of macrocycles using RCM, an X-ray crystal structure of one of the host-guest complexes would deliver the definite proof for the perfect macrocyclic structure of compounds $\mathbf{7}$ and for the reattachment of $\mathbf{7 a}, \mathbf{7 d}$ and $7 \mathbf{f}$ to template 3. Crystallization of 9a from several solvent mixtures resulted in colorless crystals, however, in each case the quality of these crystals was too poor to resolve the crystal structure (too much disorder in the crystals). Therefore, we decided to replace the tetrafluoroborate counter ions of $\mathbf{9 a}$ for tetraphenylborate ions by reacting $9 \mathbf{a}$ in acetone with sodium tetraphenylborate, affording host-guest complex 10 (Scheme 4). Crystallization of the resulting tris(tetraphenylborate) hostguest complex 10 from an acetone/diethyl ether mixture, resulted in colorless crystals which could be resolved by an X-ray crystal structure determination (Figure 2). For comparison, we also crystallized the template molecule 3 from a dichloromethane/diethyl ether mixture and determined the X-ray crystal structure (Figure 3). The structure of the $\mathrm{Pd}-\mathrm{Br}$ version of tripincer $\mathbf{3}$ is also known. ${ }^{[7]}$ As shown in Figure 3, the molecular structure of the template precursor 3 consists of a central benzene ring that is substituted at the 1-, 3-, and 5-positions with pincer-platinum moieties. Since the template possesses exact $D_{3}$ molecular symmetry, the three pincer-platinum groups have the same geometry and orientation. The twist angle between the planes of the central ring and the pincer aryl rings is $40.2(2)^{\circ}$. The pincer groups are cycloplatinated at the position between the two $\mathrm{CH}_{2} \mathrm{NMe}_{2}$ substituents, yielding two five-membered $\mathrm{PtCN}_{2}$ chelate rings per square planar platinum atom. A chloride anion trans to $\mathrm{C}_{i p s o}$ completes the square planar coordination environment of each platinum(II) center. The shape of the framework is most easily approximated as an equilateral triangle with sides defined by the $\mathrm{Cl}-\mathrm{Cl}$ distance of 17.281(2) $\AA$. In the crystal structure of 10, the peripheral chloride anions in $\mathbf{3}$ are replaced by the pyridine $\mathrm{N}$ atoms of the neutral macrocyclic ligand $\mathbf{7 a}$ (Figure 2); the $\mathrm{N}-\mathrm{N}$ distances in the coordinated ligand range from 16.684(7) to 17.196(6) $\AA$. The three pyridine rings, which are linked by saturated $\mathrm{O}\left(\mathrm{CH}_{2}\right)_{18} \mathrm{O}$ bridges, are oriented at angles of 84.3(4) to $89.8(3)^{\circ}$ with respect to the square planar $\mathrm{PtCN}_{3}$ coordination planes. The overall shape of the template is retained upon reattachment of the trispyridine macrocycle, but the molecular symmetry is reduced. Each of the pincer-platinum moieties in $\mathbf{1 0}$ is tilted at a different angle with respect to the central benzene ring, the twist angles between the different individual pincer aryl rings and the central aryl ring ranging from 25.6(3) to 85.1(5) ${ }^{\circ}$.

Attempts have also been made to perform RCM employing the high-oxidation state Mo-based alkylidene systems developed by Schrock. ${ }^{[8 \mathrm{dd}]}$ This was investigated, in part, to test the ability of the Pt cation to protect the Lewis basic pyridine nitrogen ${ }^{[13]}$ as the highly electrophilic Schrock system is also sensitive to deactivation by pyridine functionalities due to blockage of reactive sites by the Lewis base. ${ }^{\left[{ }^{[d]}\right]}$ Also of interest is comparison of the RCM reaction using the highly active Schrock system and that of the similarly active second-generation Grubbs' catalyst, where lower amounts of the desired macrocycle were obtained (vide supra). Using identical conditions to the aforementioned RCM reaction using 


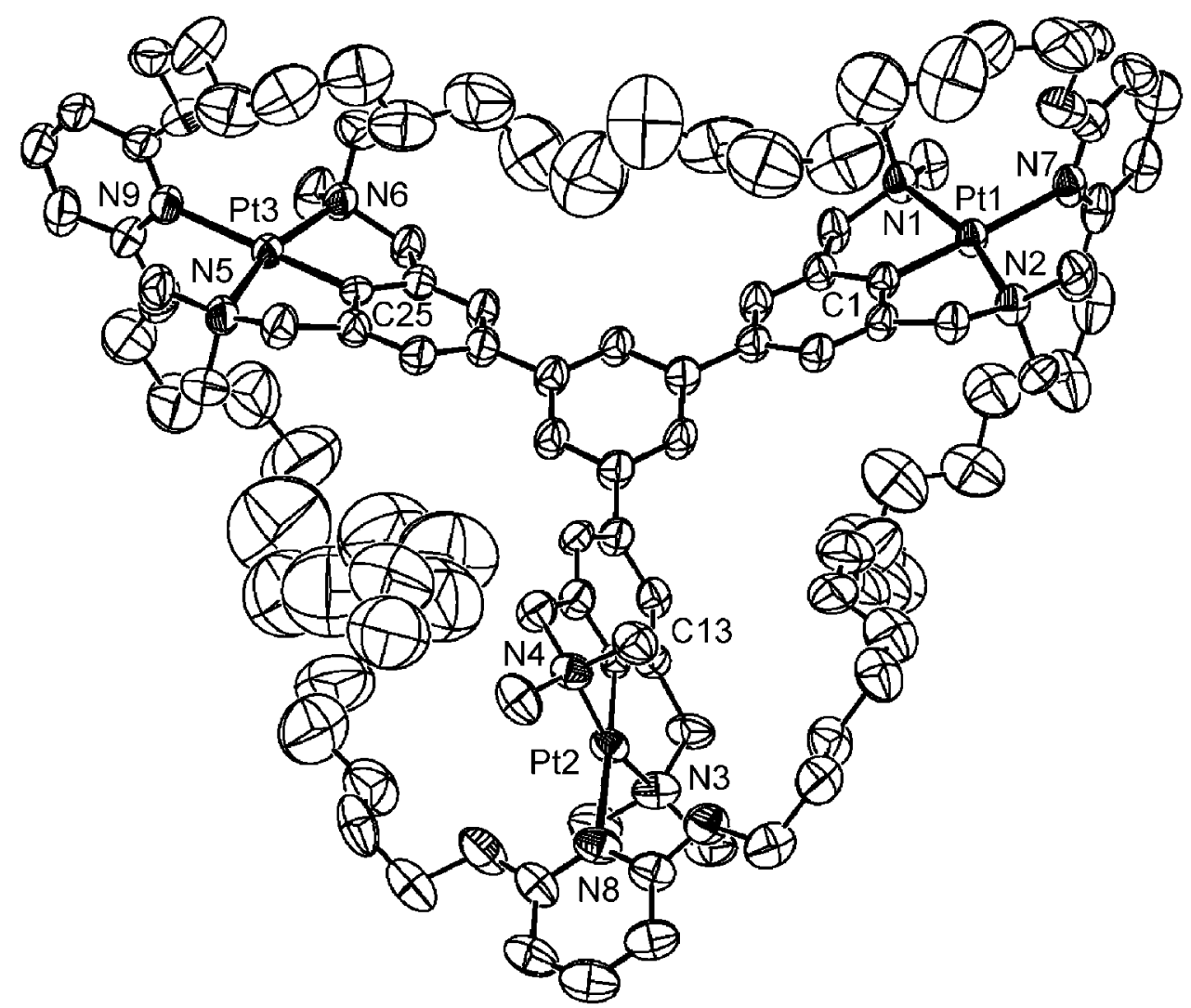

Figure 2. ORTEP representation (50\% probability) of $\mathbf{1 0}$. The tetraphenylborate anions and hydrogen atoms have been omitted for clarity. Only the major conformation of each of the disordered groups is shown.

the Grubbs' systems, 5 mol \% (per pyridine) of bis(hexafluoro-tert-butoxide)(2,6-diisopropylphenylimido) (neophylidene)molybdenum (11) was reacted with pyridineligated tricationic $\mathrm{Pt}$ pincer $\mathbf{4 a}$ in dichloromethane (see Scheme 5). Reactions at room temperature over the course of $16 \mathrm{~h}$ indicated partial formation of internal olefins, consistent with metathesis. Significant conversion to internal olefin, $>88 \%$ based on integrated olefin signals in the ${ }^{1} \mathrm{H}$ NMR spectrum, was observed on prolonged reaction at room temperature ( $>30$ hours) or upon reflux for 16 hours.

Detachment of the pyridine with aqueous $\mathrm{NaCl}$ and purification of the product by preparative TLC resulted in isolation of a single band; no product bands for dimeric or higher-order linear or cyclic oligomers were noted and the yield of the isolated product was $67 \%$. Analysis of the product by ${ }^{1} \mathrm{H}$ and ${ }^{13} \mathrm{C} \mathrm{NMR}$ spectroscopy, as well as ${ }^{1} \mathrm{H}-{ }^{1} \mathrm{H}$ COSY and ${ }^{1} \mathrm{H}_{-}{ }^{13} \mathrm{C}$ HETCOR, and by GC/MS indicated that extensive olefin isomerization had occurred in the "tails" to give mixed cis/trans products of type 12 (Scheme 5) and that no productive metathesis products were evident. The mass spectrum obtained exhibits a molecular ion peak at $\mathbf{M}=388(\mathrm{~m} / \mathrm{z})$, equivalent to those of the starting pyridine $\mathbf{1 a}$; products of olefin metathesis would exhibit mass values of [M - 14] and
[M - 28] due to loss of one and two methylene units, respectively. Further evidence for isomerization was found in the ${ }^{1} \mathrm{H}$ NMR spectrum where multiple sets of triplets at $\delta=0.86-0.96$ were observed, indicating that numerous chemo-isomeric internal olefin products are present due to further inward migration of the double bond. In addition, the ${ }^{13} \mathrm{CNMR}$ spectrum exhibits multiple ( $>$ ten) carbon signals at $\delta=123.8-132.2$ that correlate via HETCOR to the broad multiplet at $\delta=5.4$ in the ${ }^{1} \mathrm{H}$ NMR spectrum, again due to multiple internal olefins.

Olefin isomerization is a known, albeit typically minor, side-reaction that is promoted by a number of active olefin metathesis catalysts. The original "ill-defined" heterogeneous catalyst systems are known to promote olefin isomerization ${ }^{[8 \mathrm{e}, 18]}$ and there are a small number of reports in which the Grubbs-type Ru-based systems also exhibit this feature, ${ }^{[19,20]}$ with second-generation catalysts exhibiting a greater propensity to accelerate isomerization in some cases. ${ }^{[21]}$ The Schrock Mo-based systems are also known in isolated cases to catalyze olefin isomerization, although typically to a lesser extent. ${ }^{[22]}$ One example of olefin isomerization with $\mathbf{1 1}$ before RCM was reported in the attempted synthesis of a eunicellin diterpene derivative. ${ }^{[23]}$ 


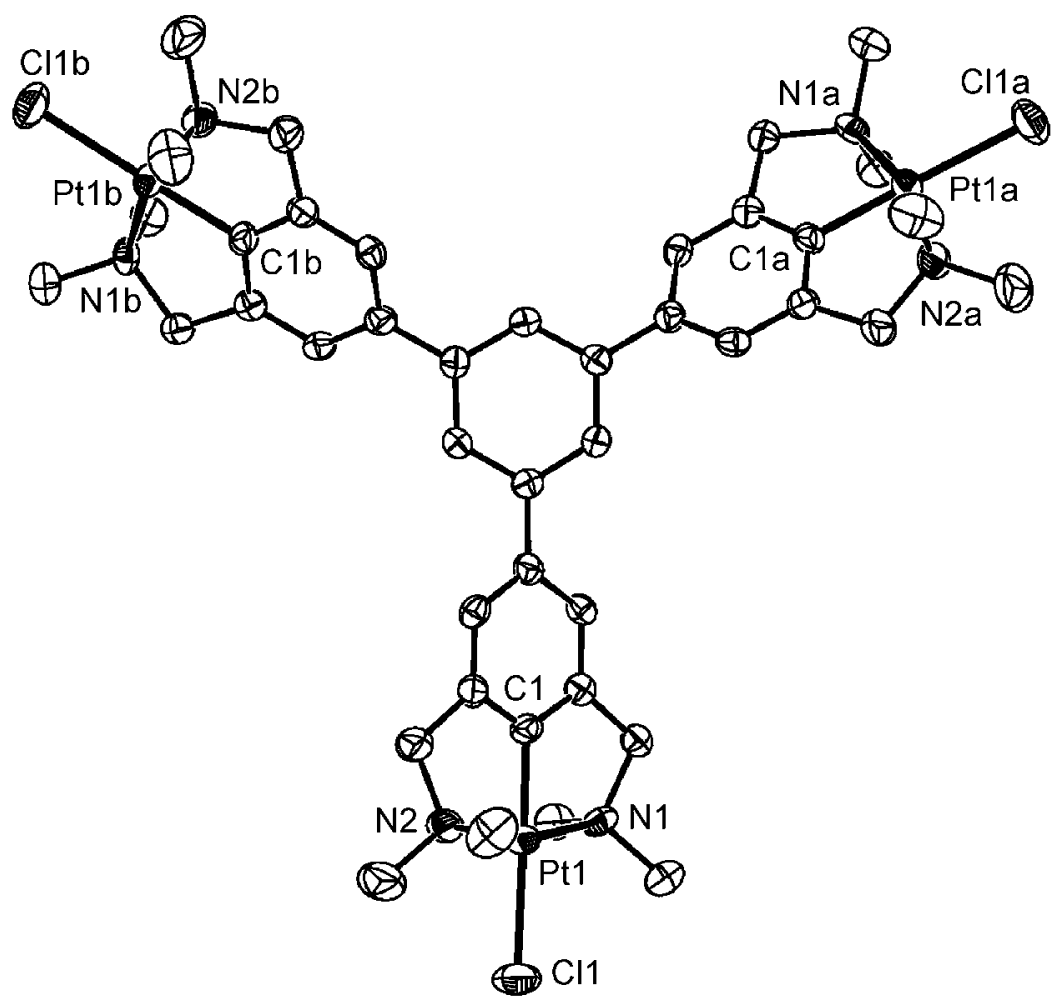

Figure 3. ORTEP representation (50\% probability) of the template precursor 3. Hydrogen atoms have been omitted for clarity.

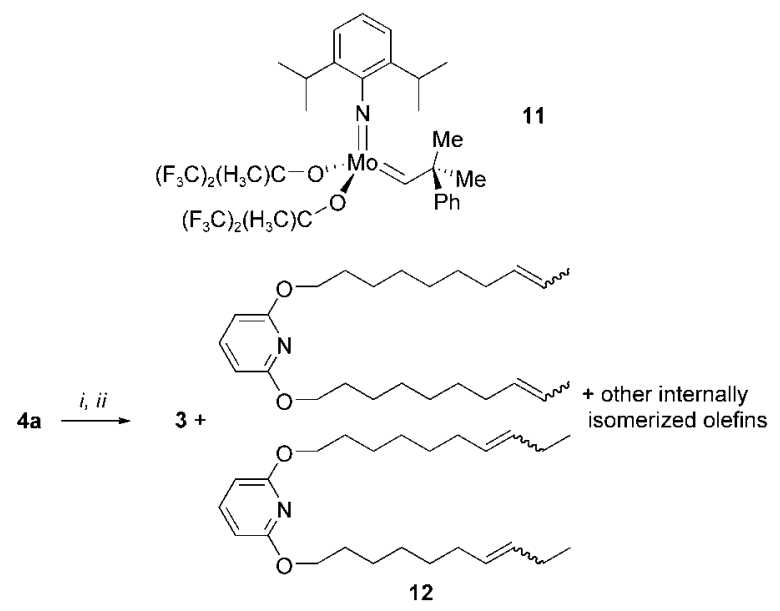

Scheme 5. Olefin isomerization using Schrock catalyst 11. $i$ ) 5 mol \% (per pyridine) $\mathbf{1 1}, \mathrm{CH}_{2} \mathrm{Cl}_{2}$, reflux. ii) $\mathrm{NaCl}, \mathrm{H}_{2} \mathrm{O}$.

The data presented herein suggest that $\mathbf{1 1}$ is not compatible with the cationic platinated pincer pyridines in olefin metathesis. However, the combination of these species generates an efficient olefin isomerization catalyst. Olefin isomerization was also noted during preliminary studies employing mono-platinated and -palladated pincers. ${ }^{[13]}$ In these cases, however, platinum species with sufficiently elongated alkyl chains exhibited essen- tially no isomerization and did not react at room temperature. Also, catalyst $\mathbf{1 1}$ is known to catalyze metathesis of internal olefins under the conditions (temperature and solvent) employed ${ }^{[8 \mathrm{~d}]}$ and, as such, the composition of the catalyst may have been altered by reaction with species present in the mixture. The exact nature of this olefin isomerization catalyst is under investigation and utility of combination olefin metathesis/isomerization is being explored.

\section{Conclusion}

An efficient and selective method to prepare macroheterocycles using templated synthesis is reported. We have shown that the tris-NCN-Pt pincer complex 3 is a suitable template for the construction of macroheterocycles from pyridines containing two olefinic side chains using RCM methodology with Grubbs' Ru-based catalysts. This procedure yielded four different macrocycles in which the side-chains connecting the pyridine moieties contain different functionalities, showing the versatility of this method. However, the combination of NCN-Pt pincer pyridine complexes and Schrock Mobased catalyst $\mathbf{1 1}$ resulted only in olefin isomerization products. Only 2,6-diolefin substituted pyridines afford trispyridinediyl-containing macroheterocycles whereas 
3,5-diolefin substituted pyridines form pyridinophane macroheterocycles under RCM conditions (thus intrapyridine RCM). Also the use of template-bound 2,6-bisolefin substituted pyridines with olefin side-chain less then 11 atoms $(\mathrm{O}, \mathrm{C})$ did not produce trispyridinediylcontaining macroheterocycles due to insufficient lengths of the olefinic tails; instead oligomeric pyridine products were obtained. The best yield of trispyridinediyl-containing macroheterocycles (67\% for 6a) using this particular triplatinum template (3) was obtained for 2,6bisolefin substituted pyridines with olefin chains containing 11 atoms $(\mathrm{O}, \mathrm{C})$ whereas for substrates with longer olefin chains ( 12 or 13 atoms) the yields of the corresponding trispyridinediyl-containing macroheterocycles decreased. The macroheterocycles (hosts) could easily be detached from the macromolecular template (guest) and quantitatively be reattached to the template after hydrogenation of the double bonds of the macrocycles. An X-ray crystal structure of host-guest complex 10 provided the definite proof for the perfect cyclic structure of the macrocycle (9a) and for the efficient reattachment of macrocycle $\mathbf{9 a}$ (host) to template $\mathbf{3}$ (guest). Comparison between the crystal structures of the template precursor $\mathbf{3}$ and cationic complex $\mathbf{1 0}$ revealed that attachment of the macrocycle to the trisplatinum complex can cause ligand-induced conformational changes in the complex (e.g., changes in dihedral angles) in the solid phase and presumably also in solution.

This study shows that it is rather easy to create macrocycles making use of highly symmetric shape-persistent macromolecular templates. We believe (and work described in literature for single-metal templates supports this $)^{[9,12]}$ that this methodology is not just restricted to pyridines and the macromolecular template used in our work. In earlier work, we have already reported the preparation of various shape-persistent templates with different dimensions and containing up to twelve metal-sites for ligand coordination. ${ }^{[7]}$ Thus combining our shape-persistent macromolecular templates with a variety of bisolefin-substituted ligands (e.g., also with $\mathrm{P}$ - and S-coordination to the metal) can lead to a large number of macroheterocycles containing many functionalities, which can subsequently be used in host-guest chemistry. As described above, the stilbene-functionalized macroheterocycle 6e underwent photo-isomerization of the initially formed all-trans macrocycle to give a mixture of the corresponding trans-trans-cis, transcis-cis, and cis-cis-cis macrocycles. This may potentially be used to reversibly switch the size and conformation of the macrocyclic host and thus tailor the affinity for the guests it can accommodate. ${ }^{[2]}$ Furthermore, giant crown-ether like macrocycles (such as 7d) could serve as hosts for other guests. For example, (polyether)pyridine macrocycle 7d is comprised of an 81-membered ring containing as much as 24 oxygen and 3 (pyridine) nitrogen atoms, which could, for example, host lanthanide and actinide ions; due to its size, it may also be used for the complexation of several guests (e.g., cations) within one macrocycle. ${ }^{[25]}$ We are currently further investigating the host-guest properties mentioned above and we will present the results in due time.

\section{Experimental Section}

All reactions were carried out using standard Schlenk techniques under an inert atmosphere of dry, oxygen-free nitrogen unless stated otherwise. All solvents were carefully dried and distilled over appropriate drying agents prior to use. All standard reagents were purchased from Acros or Aldrich. First- and second-generation Grubbs' Ru catalysts and Schrock Mo catalyst 11 were purchased from Strem. 2,6-Bis(5-hexenyloxy)pyridine (1) $)^{[13]}$ 2,6-bis[(5-hexenyloxy)methyl]pyridine (1) $)^{[13]}$ and $\mathbf{3}^{[7 \mathrm{a}]}$ were obtained according to literature procedures. ${ }^{1} \mathrm{H}$ (200 or $300 \mathrm{MHz}$ ) and ${ }^{13} \mathrm{C}(50$ or $75 \mathrm{MHz}$ ) NMR spectra were recorded on a Varian AC200 or Inova $300 \mathrm{MHz}$ spectrometer at $25^{\circ} \mathrm{C}$, chemical shifts are in ppm referenced internally to residual solvent signals. GC/MS analysis was performed using the following conditions: column PE-17; $30 \mathrm{~m} \times 0.32 \mathrm{~mm}^{2}=50 \mu \mathrm{m}$ film thickness; gas chromatograph: Perkin-Elmer Autosystem XL; mass spectrometer: Perkin-Elmer Turbomass. ES-MS analysis was performed on a Micromass Quattro Ultima spectrometer. Preparative TLC was performed using Merck 1.13895 plates, adsorbent - silica $60 \mathrm{~F}_{254}$, layer thickness $1 \mathrm{~mm}$.

\section{2,6-Bis(9-decenyloxy)pyridine (1a)}

Sodium foil $(0.74 \mathrm{~g}, 32 \mathrm{mmol})$ was added to a solution of 9-decen-1-ol $(5.0 \mathrm{~g}, 32 \mathrm{mmol})$ in THF $(50 \mathrm{~mL})$. The mixture was stirred at reflux until all sodium had dissolved, after which the THF was evaporated under reduced pressure. Dry DMF $(50 \mathrm{~mL})$ and 2,6-dibromopyridine $(3.79 \mathrm{~g}, 16 \mathrm{mmol})$ were added to the residue and the mixture was stirred at $95^{\circ} \mathrm{C}$ overnight. The DMF was evaporated and the residue was dissolved in water $(15 \mathrm{~mL})$ and extracted with $\mathrm{Et}_{2} \mathrm{O}(3 \times 50 \mathrm{~mL})$. The organic extracts were combined, dried $\left(\mathrm{MgSO}_{4}\right)$, and filtered. After evaporation of the solvent the crude product was flash distilled under vacuum. Yield: $6.0 \mathrm{~g}(97 \%)$, colorless oil. ${ }^{1} \mathrm{H}$ NMR $\left(200 \mathrm{MHz}, \mathrm{CDCl}_{3}\right): \delta=1.33(\mathrm{~m}, 20 \mathrm{H}), 1.76(\mathrm{~m}, J=7.0 \mathrm{~Hz}$, $4 \mathrm{H}), 2.05(\mathrm{~m}, J=7.0 \mathrm{~Hz}, 4 \mathrm{H}), 4.23(\mathrm{t}, J=7.0 \mathrm{~Hz}, 4 \mathrm{H}), 4.97$ $(\mathrm{m}, 4 \mathrm{H}), 5.82(\mathrm{~m}, 2 \mathrm{H}), 6.25(\mathrm{~d}, J=7.7 \mathrm{~Hz}, 2 \mathrm{H}), 7.45(\mathrm{t}, J=$ $7.7 \mathrm{~Hz}, 1 \mathrm{H}) ;{ }^{13} \mathrm{C}$ NMR $\left(75 \mathrm{MHz}, \mathrm{CDCl}_{3}\right): \delta=26.3,29.1,29.2$, 29.3, 29.5, 29.6, 33.9, 66.1, 101.1, 114.3, 139.3, 140.9, 163.0; GC/MS: $m / z=388$ (calcd. for $\mathrm{C}_{25} \mathrm{H}_{41} \mathrm{NO}_{2}$ : 387.6); anal. calcd. for $\mathrm{C}_{25} \mathrm{H}_{41} \mathrm{NO}_{2}$ : C 77.47, $\mathrm{H}$ 10.66, N 3.61; found: C 77.39, $\mathrm{H}$ $10.60, \mathrm{~N} 3.54$.

\section{2-[2-(Allyloxy)ethoxy]ethan-1-ol}

Sodium (10 g, $0.43 \mathrm{~mol})$ was dissolved in diethylene glycol $(100 \mathrm{~mL}, 112 \mathrm{~g}, 1.05 \mathrm{~mol})$ at $100^{\circ} \mathrm{C}$ under stirring and allyl bromide $(35.4 \mathrm{~mL}, 48.4 \mathrm{~g}, 0.40 \mathrm{~mol})$ was added dropwise under stirring. The reaction mixture was stirred at $100^{\circ} \mathrm{C}$ for $2 \mathrm{~h}$, cooled to room temperature and filtered. The crude product was distilled from the reaction mixture under vacuum (bp $\left.61-80{ }^{\circ} \mathrm{C} / 0.8 \mathrm{~mm}\right)$. For further purification the crude product was redistilled under vacuum (bp $58^{\circ} \mathrm{C} / 0.7 \mathrm{~mm}$ ). Yield: $49 \mathrm{~g}$ 
(84\%), colorless oil. ${ }^{1} \mathrm{H}$ NMR $\left(200 \mathrm{MHz}, \mathrm{CDCl}_{3}\right): \delta=2.45(\mathrm{t}$, $J=6 \mathrm{~Hz}, 1 \mathrm{H}), 3.57-3.78(\mathrm{~m}, 8 \mathrm{H}), 4.03(\mathrm{dt}, J=5.9 \mathrm{~Hz}, 2 \mathrm{H})$ $5.19(\mathrm{dm}, J=10.3 \mathrm{~Hz}, 1 \mathrm{H}), 5.27(\mathrm{dm}, J=17.2 \mathrm{~Hz}, 1 \mathrm{H}), 5.92$ (m, $1 \mathrm{H}) ;{ }^{13} \mathrm{C}$ NMR $\left(50 \mathrm{MHz}, \mathrm{CDCl}_{3}\right): \delta=61.8,69.5,70.5$, 72.3, 72.6, 117.4, 134.5; anal. calcd. for $\mathrm{C}_{7} \mathrm{H}_{14} \mathrm{O}_{3}$ : C 57.51, $\mathrm{H}$ 9.65; found: C 57.52, H, 9.60.

\section{2,6-Bis\{2-[2-(allyloxy)ethoxy]ethoxy\}pyridine (1c)}

2-[2-(Allyloxy)ethoxy]ethan-1-ol (10 g, $68 \mathrm{mmol})$ was dissolved in DMF $(50 \mathrm{~mL})$ and sodium hydride $(1.7 \mathrm{~g}, 71 \mathrm{mmol})$ was added. The reaction mixture was stirred for $30 \mathrm{~min}$ and 2,6-dibromopyridine ( $7.5 \mathrm{~g}, 32 \mathrm{mmol}$ ) was added. The reaction mixture was stirred overnight at $100^{\circ} \mathrm{C}$. The solvent was evaporated under vacuum, the residue was dissolved in $\mathrm{Et}_{2} \mathrm{O}$ $(100 \mathrm{~mL})$, filtered, and washed with water $(3 \times 50 \mathrm{~mL})$. After evaporating the $\mathrm{Et}_{2} \mathrm{O}$ under vacuum, the crude product was flash distilled under vacuum (bp $190^{\circ} \mathrm{C} / 0.5 \mathrm{~mm}$ ). Yield: $9.8 \mathrm{~g}$ (84\%), colorless oil. ${ }^{1} \mathrm{H}$ NMR $\left(300 \mathrm{MHz}, \mathrm{CDCl}_{3}\right): \delta=3.62(\mathrm{t}$, $J=4.4 \mathrm{~Hz}, 4 \mathrm{H}), 3.71(\mathrm{t}, J=4.4 \mathrm{~Hz}, 4 \mathrm{H}), 3.83(\mathrm{t}, J=5.0 \mathrm{~Hz}$, $4 \mathrm{H}), 4.02(\mathrm{dt}, J=5.5 \mathrm{~Hz}, 4 \mathrm{H}), 4.42(\mathrm{t}, J=5.0 \mathrm{~Hz}, 4 \mathrm{H}), 5.17$ $(\mathrm{dq}, J=10.4 \mathrm{~Hz}, 2 \mathrm{H}), 5.27(\mathrm{dq}, J=17.1 \mathrm{~Hz}, 2 \mathrm{H}), 5.91(\mathrm{~m}$, $2 \mathrm{H}), 6.32(\mathrm{~d}, J=7.9 \mathrm{~Hz}, 2 \mathrm{H}), 7.45(\mathrm{t}, J=7.9 \mathrm{~Hz}, 1 \mathrm{H}) ;{ }^{13} \mathrm{C}$ NMR $\left(75 \mathrm{MHz}, \mathrm{CDCl}_{3}\right): \delta=65.2,69.6,69.9,70.9,72.4,101.9$, 117.3, 134.9, 141.1, 162.4; anal. calcd. for $\mathrm{C}_{19} \mathrm{H}_{29} \mathrm{NO}_{6}$ : C 62.11, H 7.96, N 3.81; found: C 62.06, H 7.86, N 3.90.

\section{2-\{2-[2-(Allyloxy)ethoxy]ethoxy\}ethan-1-ol}

Sodium $(8 \mathrm{~g}, 0.35 \mathrm{~mol})$ was dissolved in triethylene glycol $(100 \mathrm{~mL}, 112 \mathrm{~g}, 0.75 \mathrm{~mol})$ at $100^{\circ} \mathrm{C}$ under stirring. The reaction mixture was cooled to $50^{\circ} \mathrm{C}$ and allyl bromide $(30 \mathrm{~mL}, 42 \mathrm{~g}$, $0.35 \mathrm{~mol}$ ) was added dropwise under stirring and the reaction mixture was stirred at $100^{\circ} \mathrm{C}$ for $2 \mathrm{~h}$. The crude product was distilled from the reaction mixture under vacuum (bp $89-97^{\circ} \mathrm{C} /$ $0.3 \mathrm{~mm}$ ). For purification the crude product was redistilled under vacuum (bp $\left.91-92^{\circ} \mathrm{C} / 0.3 \mathrm{~mm}\right)$. Yield: $61 \mathrm{~g}(92 \%)$, colorless oil. ${ }^{1} \mathrm{H} \mathrm{NMR}\left(300 \mathrm{MHz}, \mathrm{CDCl}_{3}\right): \delta=2.57(\mathrm{~s}, 1 \mathrm{H}), 3.58(\mathrm{~m}, 4 \mathrm{H})$ $3.65(\mathrm{~m}, 6 \mathrm{H}), 3.70(\mathrm{t}, J=4.4 \mathrm{~Hz}, 2 \mathrm{H}), 4.00(\mathrm{dq}, J=5.7 \mathrm{~Hz}, 2 \mathrm{H})$, $5.16(\mathrm{dm}, J=10.4 \mathrm{~Hz}, 1 \mathrm{H}), 5.25(\mathrm{dm}, J=17.1 \mathrm{~Hz}, 1 \mathrm{H}), 5.89(\mathrm{~m}$, $1 \mathrm{H}) ;{ }^{13} \mathrm{CNMR}\left(50 \mathrm{MHz}, \mathrm{CDCl}_{3}\right): \delta=61.9,69.5,70.5,70.7,70.8$ 72.4, 72.6, 117.3, 134.8; anal. calcd. for $\mathrm{C}_{9} \mathrm{H}_{18} \mathrm{O}_{4}$ : C 56.82, H 9.54; found: C 57.02, H 9.60 .

\section{2,6-Bis(2-\{2-[2- (allyloxy)ethoxy]ethoxy\}ethoxy)pyridine (1d)}

2-\{2-[2-(Allyloxy)ethoxy]ethoxy\}ethan-1-ol (10 g, $53 \mathrm{mmol})$ was dissolved in dry DMF $(50 \mathrm{~mL})$ and sodium hydride $(1.3 \mathrm{~g}, 54 \mathrm{mmol})$ was added. The reaction mixture was stirred for $30 \mathrm{~min}$ and 2,6-dibromopyridine $(6 \mathrm{~g}, 25 \mathrm{mmol})$ was added. The reaction mixture was stirred overnight at $100^{\circ} \mathrm{C}$. The DMF was evaporated under vacuum, the residue was dissolved in $\mathrm{Et}_{2} \mathrm{O}(100 \mathrm{~mL})$, filtered and washed with water $(3 \times 50 \mathrm{~mL})$. $\mathrm{Et}_{2} \mathrm{O}$ was evaporated under vacuum, any volatile impurities were removed under vacuum at $170^{\circ} \mathrm{C} / 0.9 \mathrm{~mm}$. Next, the crude product was flash distilled under vacuum. Yield: $9.4 \mathrm{~g}(82 \%)$, colorless oil. ${ }^{1} \mathrm{H}$ NMR $\left(300 \mathrm{MHz}, \mathrm{CDCl}_{3}\right): \delta=3.57-3.72(\mathrm{~m}$, $16 \mathrm{H}), 3.82(\mathrm{t}, J=5.0 \mathrm{~Hz}, 4 \mathrm{H}), 4.01(\mathrm{dt}, J=5.7 \mathrm{~Hz}, 4 \mathrm{H}), 4.41$ $(\mathrm{t}, J=4.9 \mathrm{~Hz}, 4 \mathrm{H}), 5.16(\mathrm{dm}, J=10.4 \mathrm{~Hz}, 2 \mathrm{H}), 5.25(\mathrm{dq}, J=$
$17.3 \mathrm{~Hz}, 2 \mathrm{H}), 5.90(\mathrm{~m}, 2 \mathrm{H}), 6.31(\mathrm{~d}, J=7.9 \mathrm{~Hz}, 2 \mathrm{H}), 7.45(\mathrm{t}$, $J=7.9 \mathrm{~Hz}, 1 \mathrm{H}) ;{ }^{13} \mathrm{C}$ NMR $\left(75 \mathrm{MHz}, \mathrm{CDCl}_{3}\right): \delta=65.2,69.6$, 69.8, 70.8, 70.8, 72.3, 101.9, 117.2, 134.9, 141.1, 162.4; anal. calcd. for $\mathrm{C}_{23} \mathrm{H}_{37} \mathrm{NO}_{8}$ : C 60.64, H 8.19, N 3.07; found: C 60.48, H 8.12, N 3.14 .

\section{6-(4-Vinylphenyl)hexan-1-ol}

A $1 \mathrm{M}$ solution of $\mathrm{BH}_{3}$-THF complex in THF $(50 \mathrm{~mL})$ was added dropwise under stirring to a colorless solution of 5-hexen-1ol $(5 \mathrm{~g}, 50 \mathrm{mmol})$ in THF $(50 \mathrm{~mL})$ at $-78^{\circ} \mathrm{C}$. The reaction mixture was allowed to warm up under stirring to room temperature (evolution of hydrogen was observed) and stirred for 2 h. Subsequently, $\mathrm{NaOH}(8 \mathrm{~g}, 0.2 \mathrm{~mol})$ in water $(40 \mathrm{~mL})$ was added dropwise very slowly under slow stirring to the reaction mixture. Vigorous evolution of hydrogen was observed. The reaction mixture was stirred for 15 minutes and $p$-bromostyrene (9.15 g, $50 \mathrm{mmol}), \mathrm{Pd}\left(\mathrm{PPh}_{3}\right)_{2} \mathrm{Cl}_{2}(0.7 \mathrm{~g}, 1 \mathrm{mmol})$, and $\mathrm{PPh}_{3}$ $(0.13 \mathrm{~g}, 0.5 \mathrm{mmol})$ were added to the reaction mixture. The reaction mixture was then stirred at reflux for $8 \mathrm{~h}$, cooled to room temperature and filtered. The solvent was evaporated under vacuum, and $\mathrm{Et}_{2} \mathrm{O}(200 \mathrm{~mL})$ and $\mathrm{NaOH}(10 \mathrm{~g})$ in water $(40 \mathrm{~mL})$ were added to the residue. The organic layer was separated, the aqueous layer was extracted with $\mathrm{Et}_{2} \mathrm{O}(3 \times 50 \mathrm{~mL})$, and the combined organic extracts were dried over $\mathrm{MgSO}_{4}$, filtered and evaporated. The thus obtained crude product was flash distilled under vacuum. Yield $6.6 \mathrm{~g}$ (65\%), colorless oil. This compound should be stored in a freezer to avoid spontaneous polymerization. ${ }^{1} \mathrm{H} \mathrm{NMR}\left(200 \mathrm{MHz}, \mathrm{CDCl}_{3}\right): \delta=1.22-$ $1.44(\mathrm{~m}, 4 \mathrm{H}), 1.44-1.75(\mathrm{~m}, 5 \mathrm{H}), 2.61(\mathrm{t}, J=7.5 \mathrm{~Hz}, 2 \mathrm{H}), 3.63$ $(\mathrm{t}, J=6.4 \mathrm{~Hz}, 2 \mathrm{H}), 5.19(\mathrm{~d}, J=11.0 \mathrm{~Hz}, 1 \mathrm{H}), 5.71(\mathrm{~d}, J=$ $17.2 \mathrm{~Hz}, 1 \mathrm{H}), 6.70$ (dd, $J=17.6 \mathrm{~Hz}, J=10.6 \mathrm{~Hz}, 1 \mathrm{H}), 7.14$ (d, $J=8.2 \mathrm{~Hz}, 2 \mathrm{H}), 7.33(\mathrm{~d}, J=8.0 \mathrm{~Hz}, 2 \mathrm{H}) ;{ }^{13} \mathrm{C} \mathrm{NMR}(50 \mathrm{MHz}$, $\left.\mathrm{CDCl}_{3}\right): \delta=25.8,29.2,31.5,32.9,35.8,63.1,112.9,126.2$, 128.6, 135.1, 136.7, 142.5; anal. calcd. for $\mathrm{C}_{14} \mathrm{H}_{20} \mathrm{O}: \mathrm{C} 82.30, \mathrm{H}$ 9.87; found: C 82.22, H 9.79.

\section{2,6-Bis\{[6-(4-vinylphenyl)hexyl]oxy\}pyridine (1e)}

6-(4-Vinylphenyl)hexan-1-ol (3.7 g, $18 \mathrm{mmol})$ was dissolved in dry DMF $(50 \mathrm{~mL})$ and sodium hydride $(0.48 \mathrm{~g}, 20 \mathrm{mmol})$ was added. The reaction mixture was stirred for $30 \mathrm{~min}$ and 2,6-dibromopyridine $(2.1 \mathrm{~g}, 9 \mathrm{mmol})$ was added. The reaction mixture was stirred overnight at $100^{\circ} \mathrm{C}$. The solvent was evaporated under vacuum, and the residue was dissolved in hexane $(100 \mathrm{~mL})$, filtered, and washed with water $(3 \times 50 \mathrm{~mL})$. The solvent was evaporated under vacuum, and the crude product was recrystallized from methanol. Four grams of the crude product were dissolved in methanol $(400 \mathrm{~mL})$ at reflux and crystallized overnight at $-30^{\circ} \mathrm{C}$ as a solvate with methanol. The crystals were filtered quickly and allowed to melt at room temperature. The resulting oil was dried under vacuum. An additional amount of the product was obtained from the mother liquor by secondary crystallization. Yield: $3.9 \mathrm{~g}$ (91\%), colorless oil. This compound should be stored in a freezer to avoid spontaneous polymerization. ${ }^{1} \mathrm{H}$ NMR $(300 \mathrm{MHz}$, $\left.\mathrm{CDCl}_{3}\right): \delta=1.36-1.56(\mathrm{~m}, 8 \mathrm{H}), 1.65(\mathrm{~m}, J=7.5 \mathrm{~Hz}, 4 \mathrm{H}), 1.77$ $(\mathrm{m}, J=7.2 \mathrm{~Hz}, 4 \mathrm{H}), 2.62(\mathrm{t}, J=7.6 \mathrm{~Hz}, 4 \mathrm{H}), 4.24(\mathrm{t}, J=$ $6.5 \mathrm{~Hz}, 4 \mathrm{H}), 5.20(\mathrm{~d}, J=10.5 \mathrm{~Hz}, 2 \mathrm{H}), 5.71(\mathrm{~d}, J=17.4 \mathrm{~Hz}$, $2 \mathrm{H}), 6.27(\mathrm{~d}, J=8.1 \mathrm{~Hz}, 2 \mathrm{H}), 6.71(\mathrm{dd}, J=17.7 \mathrm{~Hz}, J=$ 
$11.1 \mathrm{~Hz}, 2 \mathrm{H}), 7.14(\mathrm{~d}, J=8.4 \mathrm{~Hz}, 4 \mathrm{H}), 7.34(\mathrm{~d}, J=8.4 \mathrm{~Hz}, 4 \mathrm{H})$ $7.47(\mathrm{t}, J=8.0 \mathrm{~Hz}, 1 \mathrm{H}) ;{ }^{13} \mathrm{C} \mathrm{NMR}\left(75 \mathrm{MHz}, \mathrm{CDCl}_{3}\right): \delta=26.1$, 29.2, 31.5, 35.7, 66.1, 101.2, 113.0, 126.3, 128.7, 135.2, 136.9, 140.9, 142.6, 163.0; anal. calcd. for $\mathrm{C}_{33} \mathrm{H}_{41} \mathrm{NO}_{2}$ : C 81.94, $\mathrm{H}$ 8.54, N 2.90; found: C 82.08, H 8.44, N 2.88.

\section{2,6-Bis[(9-decenyloxy)methyl]pyridine (1f)}

To a solution of 9-decen-1-ol (5.0 g, $32 \mathrm{mmol})$ in THF $(50 \mathrm{~mL})$ sodium foil $(0.74 \mathrm{~g}, 32 \mathrm{mmol})$ was added. The mixture was stirred at reflux until all sodium was dissolved and 2,6-bis(chloromethyl)pyridinium chloride $(2.26 \mathrm{~g}, 10.7 \mathrm{mmol})$ was added. The mixture was stirred at reflux overnight and THF was evaporated under vacuum. The residue was dissolved in water $(15 \mathrm{~mL})$ and extracted with $\mathrm{Et}_{2} \mathrm{O}(3 \times 50 \mathrm{~mL})$. The organic extracts were combined, dried $\left(\mathrm{MgSO}_{4}\right)$, and filtered. The solvents and unreacted 9-decen-1-ol were removed under vacuum. The crude product was flash distilled at reduced pressure. Yield: $4.3 \mathrm{~g}$ (97\%), white solid. ${ }^{1} \mathrm{H}$ NMR $\left(200 \mathrm{MHz}, \mathrm{CDCl}_{3}\right)$ : $\delta=1.30(\mathrm{~m}, 20 \mathrm{H}), 1.64(\mathrm{~m}, J=7.0 \mathrm{~Hz}, 4 \mathrm{H}), 2.04(\mathrm{~m}, J=$ $7.0 \mathrm{~Hz}, 4 \mathrm{H}), 3.54(\mathrm{t}, J=6.6 \mathrm{~Hz}, 4 \mathrm{H}), 4.60(\mathrm{~s}, 4 \mathrm{H}), 4.97(\mathrm{~m}$, $4 \mathrm{H}), 5.82(\mathrm{~m}, 2 \mathrm{H}), 7.34(\mathrm{~d}, J=7.7 \mathrm{~Hz}, 2 \mathrm{H}), 7.70(\mathrm{t}, J=7.7 \mathrm{~Hz}$, $1 \mathrm{H}) ;{ }^{13} \mathrm{C} \mathrm{NMR}\left(75 \mathrm{MHz}, \mathrm{CDCl}_{3}\right): \delta=26.3,29.0,29.2,29.5$, 29.9, 33.9, 71.3, 73.9, 114.2, 119.8, 137.2, 139.3, 158.4. GC/MS: $m / z=416$ (calcd. for $\mathrm{C}_{27} \mathrm{H}_{45} \mathrm{NO}_{2}$ : 415.7); anal. calcd. for $\mathrm{C}_{27} \mathrm{H}_{45} \mathrm{NO}_{2}$ : C 78.02, H 10.91, N 3.47; found: C 78.02, H 10.91, N 3.62 .

\section{Bis(9-decenyl) 3,5-Pyridinedicarboxylate (2a)}

3,5-Pyridinedicarboxylic acid (3.2 g, $19.12 \mathrm{mmol}$ ) was suspended in $\mathrm{SOCl}_{2}(20 \mathrm{~mL}, 270 \mathrm{mmol})$ and stirred at reflux overnight. Subsequently, the excess $\mathrm{SOCl}_{2}$ was evaporated under vacuum and the remaining white solid was dissolved in $\mathrm{CH}_{2} \mathrm{Cl}_{2}(50 \mathrm{~mL})$. 9-Decane-1-ol (6.0 g, $38.4 \mathrm{mmol})$ was added to the solution and the reaction mixture was stirred at reflux for $3 \mathrm{~h}$. The volatiles were removed under vacuum, the residue was suspended in $\mathrm{Et}_{2} \mathrm{O}(50 \mathrm{~mL})$ and sodium hydroxide $(1.6 \mathrm{~g}, 40 \mathrm{mmol})$ in water $(10 \mathrm{~mL})$ was added. The reaction mixture was stirred for $15 \mathrm{~min}$, the organic layer was separated, dried over $\mathrm{MgSO}_{4}$, and filtered. The $\mathrm{Et}_{2} \mathrm{O}$ was removed in vacuum and the residue was flash distilled giving a light yellow oil. Yield: $7.8 \mathrm{~g} \mathrm{(92 \% ).}$ ${ }^{1} \mathrm{H}$ NMR $\left(200 \mathrm{MHz}, \mathrm{CDCl}_{3}\right): \delta=1.31(\mathrm{~m}, 20 \mathrm{H}), 1.78(\mathrm{~m}, J=$ $7.0 \mathrm{~Hz}, 4 \mathrm{H}), 2.03(\mathrm{q}, J=6.6 \mathrm{~Hz}, 4 \mathrm{H}), 4.37(\mathrm{t}, J=6.6 \mathrm{~Hz}, 4 \mathrm{H})$, $4.97(\mathrm{~m}, 4 \mathrm{H}), 5.79(\mathrm{~m}, 2 \mathrm{H}), 8.84(\mathrm{t}, J=2.2 \mathrm{~Hz}, 1 \mathrm{H}), 9.34(\mathrm{~d}$, $J=2.2 \mathrm{~Hz}, 2 \mathrm{H}) ;{ }^{13} \mathrm{C}$ NMR $\left(50 \mathrm{MHz}, \mathrm{CDCl}_{3}\right): \delta=26.1,28.8$, 29.0, 29.2, 29.3, 29.5, 33.9, 66.1, 114.3, 126.4, 138.1, 139.2, 154.2, 164.6. GC/MS: $m / z=444$ (calcd. for $\mathrm{C}_{27} \mathrm{H}_{41} \mathrm{NO}_{4}$ : 443.6); anal. calcd. for $\mathrm{C}_{27} \mathrm{H}_{41} \mathrm{NO}_{4}$ : C 73.10, $\mathrm{H}$ 9.32, N 3.16; found: $\mathrm{C}$ 72.97, H 9.35, N 3.24 .

\section{Cationic Complex 4a}

Template precursor $3(1.36 \mathrm{~g}, 1.02 \mathrm{mmol}), \mathrm{AgBF}_{4}(0.6 \mathrm{~g}$, $3.07 \mathrm{mmol})$, and 2,6-bis(9-decenyloxy)pyridine (1a) $(1.19 \mathrm{~g}$, $3.07 \mathrm{mmol}$ ) were mixed in dry dichloromethane $(70 \mathrm{~mL})$. The resulting mixture was stirred overnight under exclusion of light, filtered over Celite and evaporated under vacuum. Yield: $2.67 \mathrm{~g}(99 \%)$, glassy solid. ${ }^{1} \mathrm{H}$ NMR $\left(200 \mathrm{MHz}\right.$, acetone- $\left.d_{6}\right): \delta=$ $1.27(\mathrm{~m}, 60 \mathrm{H}), 1.76(\mathrm{~m}, J=7.2 \mathrm{~Hz}, 12 \mathrm{H}), 1.97(\mathrm{q}, J=7.2 \mathrm{~Hz}$,
$12 \mathrm{H}), 2.99(\mathrm{~s}, 36 \mathrm{H}), 4.33(\mathrm{~s}, 12 \mathrm{H}), 4.42(\mathrm{t}, J=6.6 \mathrm{~Hz}, 12 \mathrm{H})$, $4.90(\mathrm{~m}, 12 \mathrm{H}), 5.75(\mathrm{~m}, 6 \mathrm{H}), 6.98(\mathrm{~d}, J=8.4 \mathrm{~Hz}, 6 \mathrm{H}), 7.42(\mathrm{~s}$, $6 \mathrm{H}), 7.82(\mathrm{~s}, 3 \mathrm{H}), 8.15(\mathrm{t}, J=8.0 \mathrm{~Hz}, 3 \mathrm{H}) ;{ }^{13} \mathrm{C} \mathrm{NMR}(50 \mathrm{MHz}$, acetone- $\left.d_{6}\right): \delta=26.8,29.5,29.8,29.9,30.0,34.3,54.3,70.2$, 77.6, 101.2, 114.2, 119.5, 124.1, 138.4, 139.6, 144.1, 144.7, 145.4, 145.8, 163.9; anal. calcd. for $\mathrm{C}_{117} \mathrm{H}_{180} \mathrm{~B}_{3} \mathrm{~F}_{12} \mathrm{~N}_{9} \mathrm{O}_{6} \mathrm{Pt}_{3}$ : C 52.94, H 6.84, N 4.75; found: C 53.10, H 6.76, N 4.70.

\section{Cationic Complex 4b}

Template precursor $3(2.0 \mathrm{~g}, 1.5 \mathrm{mmol}), \mathrm{AgBF}_{4}(0.9 \mathrm{~g}$, $4.6 \mathrm{mmol}$ ), and 2,6-bis(5-hexenyloxy)pyridine (1b) (1.24 g, $4.51 \mathrm{mmol})$ were mixed in dry dichloromethane $(70 \mathrm{~mL})$. The resulting mixture was stirred overnight under the exclusion of light, filtered over Celite and evaporated under vacuum. Yield: $3.4 \mathrm{~g}(98 \%)$, glassy solid. ${ }^{1} \mathrm{H}$ NMR $(300 \mathrm{MHz}$, acetone$\left.d_{6}\right): \delta=1.84(\mathrm{~m}, J=7.2 \mathrm{~Hz}, 12 \mathrm{H}), 2.02(\mathrm{~m}, J=7.3 \mathrm{~Hz}, 12 \mathrm{H})$, $2.18(\mathrm{q}, J=7.0 \mathrm{~Hz}, 12 \mathrm{H}), 2.98(\mathrm{~s}, 36 \mathrm{H}), 4.32(\mathrm{~s}, 12 \mathrm{H}), 4.44(\mathrm{t}$, $J=6.3 \mathrm{~Hz}, 12 \mathrm{H}), 4.88(\mathrm{dm}, J=10.4 \mathrm{~Hz}, 6 \mathrm{H}), 4.97(\mathrm{dm}, J=$ $17.1 \mathrm{~Hz}, 6 \mathrm{H}), 5.80(\mathrm{~m}, 6 \mathrm{H}), 6.98(\mathrm{~d}, J=8.2 \mathrm{~Hz}, 6 \mathrm{H}), 7.43(\mathrm{~s}$, $6 \mathrm{H}), 7.83(\mathrm{~s}, 3 \mathrm{H}), 8.16(\mathrm{t}, J=8.2 \mathrm{~Hz}, 3 \mathrm{H})$; anal. calcd. for $\mathrm{C}_{93} \mathrm{H}_{132} \mathrm{~B}_{3} \mathrm{~F}_{12} \mathrm{~N}_{9} \mathrm{O}_{6} \mathrm{Pt}_{3}$ : C 48.19, $\mathrm{H}$ 5.74, $\mathrm{N}$ 5.44; found: $\mathrm{C} 48.42$, H 5.85, N 5.37.

\section{Cationic Complex 4c}

Template precursor $3(0.91 \mathrm{~g}, 0.68 \mathrm{mmol}), \mathrm{AgBF}_{4}(0.40 \mathrm{~g}$, $2.05 \mathrm{mmol}$ ), and 2,6-bis\{2-[2-(allyloxy)ethoxy]ethoxy\}pyridine (1c) $(0.752 \mathrm{~g}, 2.05 \mathrm{mmol})$ were mixed in dry dichloromethane $(70 \mathrm{~mL})$. The resulting mixture was stirred overnight under the exclusion of light and centrifuged. A slow stream of $\mathrm{H}_{2} \mathrm{~S}$ was passed through the reaction mixture for $2 \mathrm{~min}$ to remove complexed $\mathrm{Ag}^{+}$, the reaction mixture was refluxed overnight and filtered over Celite. The solvent was evaporated under vacuum. Yield: $1.67 \mathrm{~g}(94 \%)$, glassy solid. ${ }^{1} \mathrm{H}$ NMR $(300 \mathrm{MHz}$, acetone- $\left.d_{6}\right): \delta=3.00(\mathrm{~s}, 36 \mathrm{H}), 3.55(\mathrm{t}, J=4.7 \mathrm{~Hz}, 12 \mathrm{H}), 3.76(\mathrm{t}, J=$ $4.7 \mathrm{~Hz}, 12 \mathrm{H}), 3.91(\mathrm{dt}, J=5.5 \mathrm{~Hz}, J=1.5 \mathrm{~Hz}, 12 \mathrm{H}), 4.04(\mathrm{~m}$, $12 \mathrm{H}), 4.32,(\mathrm{~s}, 12 \mathrm{H}), 4.56(\mathrm{~m}, 12 \mathrm{H}), 5.09(\mathrm{dq}, J=10.4 \mathrm{~Hz}, J=$ $1.6 \mathrm{~Hz}, 6 \mathrm{H}), 5.21(\mathrm{dq}, J=17.4 \mathrm{~Hz}, J=1.8 \mathrm{~Hz}, 6 \mathrm{H}), 5.85(\mathrm{~m}$, $6 \mathrm{H}), 7.02(\mathrm{~d}, J=8.2 \mathrm{~Hz}, 6 \mathrm{H}), 7.39(\mathrm{~s}, 6 \mathrm{H}), 7.79(\mathrm{~s}, 3 \mathrm{H}), 8.18(\mathrm{t}$, $J=8.2 \mathrm{~Hz}, 3 \mathrm{H}) ;{ }^{13} \mathrm{C}$ NMR $\left(75 \mathrm{MHz}\right.$, acetone- $\left.d_{6}\right): \delta=54.4$, $69.8,69.9,70.3,71.2,72.3,77.5,101.4,116.6,119.4,124.1$, 136.1, 138.4, 144.3, 144.5, 145.9 (2C), 163.8; anal. calcd. for $\mathrm{C}_{99} \mathrm{H}_{144} \mathrm{~B}_{3} \mathrm{~F}_{12} \mathrm{~N}_{9} \mathrm{O}_{18} \mathrm{Pt}_{3}: \mathrm{C} 45.84, \mathrm{H}$ 5.60, $\mathrm{N}$ 4.86; found: $\mathrm{C} 45.71$, H 5.70, N 4.84 .

\section{Cationic Complex 4d}

Template precursor $3(1.50 \mathrm{~g}, 1.12 \mathrm{mmol}), \mathrm{AgBF}_{4}(0.66 \mathrm{~g}$, $3.38 \mathrm{mmol}), \quad$ and 2,6-bis(2-\{2-[2-(allyloxy)ethoxy]ethoxy\} ethoxy)pyridine (1d) $(1.53 \mathrm{~g}, 3.36 \mathrm{mmol})$ were mixed in dry dichloromethane $(75 \mathrm{~mL})$. The resulting mixture was stirred overnight under the exclusion of light and centrifuged. A slow stream of $\mathrm{H}_{2} \mathrm{~S}$ was passed through the reaction mixture for $2 \mathrm{~min}$ to remove complexed $\mathrm{Ag}^{+}$, the reaction mixture was subsequently refluxed overnight, and filtered over Celite. The solvent was evaporated under vacuum. Yield: $3.00 \mathrm{~g}$ (94\%), glassy solid. ${ }^{1} \mathrm{H}$ NMR $\left(300 \mathrm{MHz}\right.$, acetone- $\left.d_{6}\right): \delta=2.99$ $(\mathrm{s}, 36 \mathrm{H}), 3.49(\mathrm{~m}, 24 \mathrm{H}), 3.57(\mathrm{t}, J=4.8 \mathrm{~Hz}, 12 \mathrm{H}), 3.73(\mathrm{t}, J=$ $4.9 \mathrm{~Hz}, 12 \mathrm{H}), 3.93(\mathrm{~d}, J=5.7 \mathrm{~Hz}, 12 \mathrm{H}), 4.02(\mathrm{~m}, 12 \mathrm{H}), 4.31$, 
$(\mathrm{s}, 12 \mathrm{H}), 4.54(\mathrm{~m}, 12 \mathrm{H}), 5.08(\mathrm{dq}, J=10.5 \mathrm{~Hz}, J=1.5 \mathrm{~Hz}, 6 \mathrm{H})$, $5.21(\mathrm{dq}, J=16.8 \mathrm{~Hz}, J=2.1 \mathrm{~Hz}, 6 \mathrm{H}), 5.85(\mathrm{~m}, 6 \mathrm{H}), 7.00(\mathrm{~d}$ $J=8.1 \mathrm{~Hz}, 6 \mathrm{H}), 7.39(\mathrm{~s}, 6 \mathrm{H}), 7.81(\mathrm{~s}, 3 \mathrm{H}), 8.16(\mathrm{t}, J=8.3 \mathrm{~Hz}$ $3 \mathrm{H}) ;{ }^{13} \mathrm{C}$ NMR $\left(75 \mathrm{MHz}\right.$, acetone- $\left.d_{6}\right): \delta=54.5,69.9$, 70.0, 70.3, 71.1, 71.3, 72.3, 77.6, 101.4, 116.4, 119.5, 124.1, 136.3, 138.4, 144.4, 144.7, 145.9(2C), 163.9; anal. calcd. for $\mathrm{C}_{111} \mathrm{H}_{168} \mathrm{~B}_{3} \mathrm{~F}_{12} \mathrm{~N}_{9} \mathrm{O}_{24} \mathrm{Pt}_{3}$ : C 46.64, $\mathrm{H}$ 5.92, $\mathrm{N}$ 4.41; found: $\mathrm{C}$ 46.54, H 5.88, N, 4.34.

\section{Cationic Complex 4e}

Template precursor $3(1.0 \mathrm{~g}, 0.75 \mathrm{mmol}), \mathrm{AgBF}_{4}(0.44 \mathrm{~g}$, $2.26 \mathrm{mmol})$, and 2,6-bis \{[6-(4-vinylphenyl)hexyl]oxy\}pyridine (1e) $(1.1 \mathrm{~g}, 2.27 \mathrm{mmol})$ were mixed in dry dichloromethane $(70 \mathrm{~mL})$. The resulting mixture was stirred overnight under the exclusion of light, filtered over Celite, and evaporated under vacuum. Yield: $2.19 \mathrm{~g}$ (99\%), glassy solid. ${ }^{1} \mathrm{H}$ NMR $\left(300 \mathrm{MHz}\right.$, acetone- $\left.d_{6}\right): \delta=1.43(\mathrm{~m}, J=7.1 \mathrm{~Hz}, 12 \mathrm{H}), 1.57$ $(\mathrm{m}, J=7.4 \mathrm{~Hz}, 12 \mathrm{H}), 1.78(\mathrm{~m}, J=7.5 \mathrm{~Hz}, 12 \mathrm{H}), 1.96(\mathrm{~m}, J=$ $7.2 \mathrm{~Hz}, 12 \mathrm{H}), 2.50(\mathrm{t}, J=7.4 \mathrm{~Hz}, 12 \mathrm{H}), 2.93(\mathrm{~s}, 36 \mathrm{H}), 4.25$, (s, $12 \mathrm{H}), 4.38(\mathrm{t}, J=6.0 \mathrm{~Hz}, 12 \mathrm{H}), 5.10(\mathrm{~d}, J=11.1 \mathrm{~Hz}, 6 \mathrm{H}), 5.64$ $(\mathrm{d}, J=17.4 \mathrm{~Hz}, 6 \mathrm{H}), 6.61\left(\mathrm{dd}, J_{1}=17.7 \mathrm{~Hz}, J_{2}=10.8 \mathrm{~Hz}, 6 \mathrm{H}\right)$, $6.94(\mathrm{~d}, J=8.4 \mathrm{~Hz}, 6 \mathrm{H}), 7.02(\mathrm{~d}, J=8.1 \mathrm{~Hz}, 12 \mathrm{H}), 7.25(\mathrm{~d}, J=$ $7.8 \mathrm{~Hz}, 12 \mathrm{H}), 7.37(\mathrm{~s}, 6 \mathrm{H}), 7.83(\mathrm{~s}, 3 \mathrm{H}), 8.13(\mathrm{t}, J=8.3 \mathrm{~Hz}$ $3 \mathrm{H}) ;{ }^{13} \mathrm{C}$ NMR $\left(75 \mathrm{MHz}\right.$, acetone- $\left.d_{6}\right): \delta=26.8,29.6,29.8$, $32.0,35.9,54.4,70.3,77.7,101.3,112.9,119.7,124.4,127.0$ 129.3, 135.6, 137.6, 137.5, 143.1, 144.2, 144.7, 145.5, 145.9, 163.9; anal. calcd. for $\mathrm{C}_{141} \mathrm{H}_{180} \mathrm{~B}_{3} \mathrm{~F}_{12} \mathrm{~N}_{9} \mathrm{O}_{6} \mathrm{Pt}_{3}$ : C 57.55, H 6.17, N 4.28; found: C 57.38; H 6.19; N 4.18 .

\section{Cationic Complex 4f}

Template precursor $3(1.64 \mathrm{~g}, 1.22 \mathrm{mmol}), \mathrm{AgBF}_{4}(0.72 \mathrm{~g}$, $3.67 \mathrm{mmol}$ ), and 2,6-bis[(9-decenyloxy)methyl]pyridine (1f) $(1.53 \mathrm{~g}, 3.68 \mathrm{mmol})$ were mixed in dry dichloromethane $(70 \mathrm{~mL})$. The mixture was stirred overnight under the exclusion of light, filtered over Celite and evaporated under vacuum. Yield: $3.30 \mathrm{~g}(99 \%)$, glassy solid. ${ }^{1} \mathrm{H}$ NMR (200 MHz, acetone- $\left.d_{6}\right): \delta=1.33(\mathrm{~m}, 60 \mathrm{H}), 1.71(\mathrm{~m}, J=6.4 \mathrm{~Hz}, 12 \mathrm{H}), 2.03(\mathrm{q}$, $J=6.6 \mathrm{~Hz}, 12 \mathrm{H}), 2.96(\mathrm{~s}, 36 \mathrm{H}), 3.82(\mathrm{t}, J=6.4 \mathrm{~Hz}, 12 \mathrm{H}), 4.46$ $(\mathrm{s}, 12 \mathrm{H}), 4.96(\mathrm{~m}, 12 \mathrm{H}), 5.84(\mathrm{~m}, 18 \mathrm{H}), 7.51(\mathrm{~s}, 6 \mathrm{H}), 7.88$ $(\mathrm{s}, 3 \mathrm{H}), 7.94(\mathrm{~d}, J=7.7 \mathrm{~Hz}, 6 \mathrm{H}), 8.30(\mathrm{t}, J=7.7 \mathrm{~Hz}, 3 \mathrm{H})$ ${ }^{13} \mathrm{C}$ NMR $\left(50 \mathrm{MHz}\right.$, acetone- $\left.d_{6}\right): \delta=26.9,29.6,29.7,30.1$, 30.4, 34.4, 54.5, 72.3, 73.6, 77.9, 114.5, 119.8, 124.4, 126.6, 139.1, 139.7, 140.6, 143.9, 145.7, 158.7, 160.1; anal. calcd. for $\mathrm{C}_{123} \mathrm{H}_{192} \mathrm{~B}_{3} \mathrm{~F}_{12} \mathrm{~N}_{9} \mathrm{O}_{6} \mathrm{Pt}_{3}$ : C 53.95, H 7.07, $\mathrm{N}$ 4.60; found: C 53.86, $\mathrm{H}$ 6.94, N 4.48.

\section{Cationic Complex 4g}

Template precursor $\mathbf{3}(2.0 \mathrm{~g}, 1.5 \mathrm{mmol}), \mathrm{AgBF}_{4}(0.9 \mathrm{~g}$, $4.6 \mathrm{mmol})$, and 2,6-bis[(5-hexenyloxy)methyl]pyridine (1g) $(1.37 \mathrm{~g}, 4.5 \mathrm{mmol})$ were mixed in dry dichloromethane $(70 \mathrm{~mL})$. The mixture was stirred overnight under the exclusion of light, filtered over Celite and evaporated under vacuum. Yield: $3.53 \mathrm{~g}(98 \%)$, glassy solid. ${ }^{1} \mathrm{H}$ NMR $(200 \mathrm{MHz}$, acetone- $\left.d_{6}\right): \delta=1.55(\mathrm{~m}, 12 \mathrm{H}), 1.73(\mathrm{~m}, 12 \mathrm{H}), 2.10(\mathrm{q}, J=6.6 \mathrm{~Hz}$, $12 \mathrm{H}), 2.96(\mathrm{~s}, 36 \mathrm{H}), 3.83(\mathrm{t}, J=6.2 \mathrm{~Hz}, 12 \mathrm{H}), 4.47(\mathrm{~s}, 12 \mathrm{H})$ $4.98(\mathrm{~m}, 12 \mathrm{H}), 5.86(\mathrm{~m}, 18 \mathrm{H}), 7.51(\mathrm{~s}, 6 \mathrm{H}), 7.87(\mathrm{~s}, 3 \mathrm{H}), 7.95$ $(\mathrm{d}, J=7.7 \mathrm{~Hz}, 6 \mathrm{H}), 8.31(\mathrm{t}, J=7.9 \mathrm{~Hz}, 3 \mathrm{H}) ;{ }^{13} \mathrm{C}$ NMR $\left(50 \mathrm{MHz}\right.$, acetone- $\left.d_{6}\right): \delta=26.2,29.8,34.1,54.6,72.1,73.6$, 77.9, 114.9, 119.8, 123.4, 124.4, 126.6, 139.2, 139.4, 140.7, 144.0, 145.7, 160.1; anal. calcd. for $\mathrm{C}_{99} \mathrm{H}_{144} \mathrm{~B}_{3} \mathrm{~F}_{12} \mathrm{~N}_{9} \mathrm{O}_{6} \mathrm{Pt}_{3}$ : C 49.50, H 6.04, N 5.25; found: C 49.59, H 6.01; N 5.20.

\section{Cationic Complex $4 \mathrm{~h}$}

Template precursor $3(1.30 \mathrm{~g}, 0.97 \mathrm{mmol}), \mathrm{AgBF}_{4}(0.57 \mathrm{~g}$, $2.92 \mathrm{mmol})$, and bis(9-decenyl) 2,6-pyridinedicarboxylate (2a) $(1.30 \mathrm{~g}, 2.93 \mathrm{mmol})$ were mixed in dry dichloromethane $(70 \mathrm{~mL})$. The reaction mixture was stirred overnight under the exclusion of light and filtered over Celite. The dichloromethane was evaporated under vacuum. Yield: $2.62 \mathrm{~g}(95 \%)$, glassy solid. ${ }^{1} \mathrm{H}$ NMR $\left(300 \mathrm{MHz}\right.$, acetone- $\left.d_{6}\right): \delta=1.36(\mathrm{~m}$, $60 \mathrm{H}), 1.85(\mathrm{~m}, J=7.0 \mathrm{~Hz}, 12 \mathrm{H}), 2.04(\mathrm{q}, J=6.6 \mathrm{~Hz}, 12 \mathrm{H})$, $3.00(\mathrm{~s}, 36 \mathrm{H}), 4.46(\mathrm{~m}, 24 \mathrm{H}), 4.96(\mathrm{~m}, 12 \mathrm{H}), 5.81(\mathrm{~m}, 6 \mathrm{H}), 7.47$ $(\mathrm{s}, 6 \mathrm{H}), 7.83(\mathrm{~s}, 3 \mathrm{H}), 9.01(\mathrm{t}, J=1.8 \mathrm{~Hz}, 3 \mathrm{H}), 9.85(\mathrm{~d}, J=$ $1.8 \mathrm{~Hz}, 6 \mathrm{H}) ;{ }^{13} \mathrm{C}$ NMR $\left(75 \mathrm{MHz}\right.$, acetone- $\left.d_{6}\right): \delta=26.6,29.2$, 29.6, 29.7, 29.9, 30.1, 34.4, 54.1, 67.2, 77.8, 114.5, 119.7, 124.6, 130.89, 139.4, 139.7, 139.9, 142.8, 144.0, 146.3, 156.0, 163.7; anal. calcd. for $\mathrm{C}_{123} \mathrm{H}_{180} \mathrm{~B}_{3} \mathrm{~F}_{12} \mathrm{~N}_{9} \mathrm{O}_{12} \mathrm{Pt}_{3}$ : C 52.34, $\mathrm{H}$ 6.43, N 4.47; found: C 52.45, H 6.51, N 4.38.

\section{Macrocycle 6a}

Cationic complex 4a $(2.6 \mathrm{~g}, 0.98 \mathrm{mmol})$ and Grubbs' catalyst $\mathrm{Cl}_{2}\left(\mathrm{Cy}_{3} \mathrm{P}\right)_{2} \mathrm{Ru}=\mathrm{CHPh}(120 \mathrm{mg}, 0.147 \mathrm{mmol})$ were dissolved in dichloromethane $(1000 \mathrm{~mL})$. The mixture was refluxed overnight under stirring, cooled to room temperature and concentrated under vacuum to $200 \mathrm{~mL}$. Saturated aqueous $\mathrm{NaCl}$ $(50 \mathrm{~mL})$ was added and the mixture was stirred overnight. The organic layer was separated, dried $\left(\mathrm{MgSO}_{4}\right)$, filtered, and the solvent was evaporated. The RCM products were extracted with hexane, and separated by preparative TLC, eluent: hexane/dichloromethane $=2 / 1$. Yield: $0.71 \mathrm{~g}(67 \%)$, colorless oil, which solidifies at room temperature. ${ }^{1} \mathrm{H}$ NMR $\left(200 \mathrm{MHz}, \mathrm{CDCl}_{3}\right): \delta=1.30(\mathrm{~m}, 60 \mathrm{H}), 1.75(\mathrm{~m}, J=6.8 \mathrm{~Hz}$, $12 \mathrm{H}), 1.97(\mathrm{~m}, 12 \mathrm{H}), 4.23(\mathrm{t}, J=6.8 \mathrm{~Hz}, 12 \mathrm{H}), 5.37(\mathrm{~m}, 6 \mathrm{H})$, $6.24(\mathrm{~d}, J=8.0 \mathrm{~Hz}, 6 \mathrm{H}), 7.44(\mathrm{t}, J=7.9 \mathrm{~Hz}, 3 \mathrm{H}) ;{ }^{13} \mathrm{C}$ NMR $\left(75 \mathrm{MHz}, \mathrm{CDCl}_{3}\right): \delta=26.2,29.2,29.3,29.5,29.6,29.7$, 32.7, 66.1, 101.2, 130.5, 140.9, 163.0; ES-MS: $m / z=1079.0$ $[\mathrm{M}+\mathrm{H}]^{+}$(calcd. for $\mathrm{C}_{69} \mathrm{H}_{111} \mathrm{~N}_{3} \mathrm{O}_{6}:$ 1078.64); anal. calcd. for $\mathrm{C}_{69} \mathrm{H}_{111} \mathrm{~N}_{3} \mathrm{O}_{6}$ : C 76.83, H 10.37, N 3.90; found: C 76.68, H $10.47, \mathrm{~N} 3.83$.

To recycle the template precursor $\mathbf{3}$-insoluble in hexane the residue was washed with ethanol $(3 \times 30 \mathrm{~mL})$, dissolved in chloroform $(200 \mathrm{~mL})$ and filtered through silica. The solvents were removed by evaporation under vacuum, and $\mathbf{3}$ was quantitatively recovered.

\section{General Procedure for Extraction of Products in Preparative TLC}

After the preparative TLC was eluted, the silica from the individual bands, identified under UV light $(\lambda=254 \mathrm{~nm})$, were scrapped off the plate, collected in a beaker and stirred for 1 hour in dichloromethane $/ \mathrm{MeOH}=7 / 3(60 \mathrm{~mL})$. The silica was vacuum filtered and washed with dichloromethane/ $\mathrm{MeOH}=7 / 3(1 \times 20 \mathrm{~mL})$ and the solvent was removed under vacuum. This procedure was repeated until a constant weight 
of product was obtained (usually twice more). To extract the product from residual silica, the residues were washed with dichloromethane $(3 \times 50 \mathrm{~mL})$ and gravity filtered. The filtrate was removed and the product was dried under vacuum to obtain the macrocycles.

\section{Macrocycle 6d}

Cationic complex 4d $(2.70 \mathrm{~g}, 0.94 \mathrm{mmol})$ and first-generation Grubbs' catalyst $\mathrm{Cl}_{2}\left(\mathrm{Cy}_{3} \mathrm{P}\right)_{2} \mathrm{Ru}=\mathrm{CHPh}(117 \mathrm{mg}, 0.142 \mathrm{mmol})$ were dissolved in dichloromethane $(1000 \mathrm{~mL})$. The mixture was refluxed for $16 \mathrm{~h}$ under stirring and cooled to room temperature. Saturated aqueous $\mathrm{NaCl}(40 \mathrm{~mL})$ was added and the mixture was stirred overnight. The organic layer was separated, dried $\left(\mathrm{MgSO}_{4}\right)$, filtered, and the solvent was evaporated. The RCM products were extracted with $\mathrm{Et}_{2} \mathrm{O}$ and separated by preparative TLC, eluent: dichloromethane/acetone $=4 / 1$. Yield: $0.5 \mathrm{~g}(41 \%)$, colorless oil. ${ }^{1} \mathrm{H}$ NMR $\left(300 \mathrm{MHz}, \mathrm{CDCl}_{3}\right)$ : $\delta=3.54-3.73(\mathrm{~m}, 48 \mathrm{H}), 3.82(\mathrm{t}, J=5.5 \mathrm{~Hz}, 12 \mathrm{H}), 4.00(\mathrm{dd}$ $J=3.0 \mathrm{~Hz}, J=1.5 \mathrm{~Hz}, 10 \mathrm{H}), 4.08(\mathrm{~d}, J=4.8 \mathrm{~Hz}, 2 \mathrm{H}), 4.41(\mathrm{t}$, $J=5.1 \mathrm{~Hz}, 12 \mathrm{H}), 5.71(\mathrm{t}, J=4.5 \mathrm{~Hz}, 1 \mathrm{H}), 5.79(\mathrm{~m}, J=1.4 \mathrm{~Hz}$ $5 \mathrm{H}), 6.31(\mathrm{~d}, J=8.1 \mathrm{~Hz}, 6 \mathrm{H}), 7.46(\mathrm{t}, J=7.8 \mathrm{~Hz}, 3 \mathrm{H}) ;{ }^{13} \mathrm{C}$ NMR $\left(75 \mathrm{MHz}, \mathrm{CDCl}_{3}\right): \delta=65.2,69.6,69.8,70.8,71.3,101.9$, 129.6, 141.1, 162.4; ES-MS: $m / z=1282.63[\mathrm{M}+\mathrm{H}]^{+}$(calcd. for $\mathrm{C}_{63} \mathrm{H}_{99} \mathrm{~N}_{3} \mathrm{O}_{24}$ : 1281.66); anal. calcd. for $\mathrm{C}_{63} \mathrm{H}_{99} \mathrm{~N}_{3} \mathrm{O}_{24}$ : C 59.00, H 7.78, N 3.28; found: C 58.87, H 7.73, N 3.34.

\section{Macrocycle 6e}

Cationic complex $4 \mathbf{e}(2.15 \mathrm{~g}, 0.73 \mathrm{mmol})$ and second-generation Grubbs' catalyst $\mathrm{Cl}_{2}\left(\mathrm{Cy}_{3} \mathrm{P}\right)(\mathrm{IMes}) \mathrm{Ru}=\mathrm{CHPh}$ (279 mg, $0.33 \mathrm{mmol}$ ) were subsequently dissolved in dichloromethane $(1000 \mathrm{~mL})$. The mixture was refluxed for $48 \mathrm{~h}$ under stirring, cooled to room temperature and concentrated under vacuum to $200 \mathrm{~mL}$. Saturated aqueous $\mathrm{NaCl}(50 \mathrm{~mL})$ was added and the mixture was stirred overnight. The organic layer was separated, dried $\left(\mathrm{MgSO}_{4}\right)$, and the solvent was evaporated. The RCM products were extracted with toluene, and separated by preparative TLC, eluent: toluene/hexane $=3 / 1$. After chromatographic separation the product was recrystallized from acetone (dissolved at reflux and crystallized at $-30^{\circ} \mathrm{C}$ ) and dried under vacuum at $100^{\circ} \mathrm{C}$. Yield $0.60 \mathrm{~g}(60 \%)$, colorless oil solidifying at room temperature. ${ }^{1} \mathrm{H}$ NMR $(300 \mathrm{MHz}$, $\left.\mathrm{CDCl}_{3}\right): \delta=1.30-1.46(\mathrm{~m}, 24 \mathrm{H}), 1.66(\mathrm{~m}, J=7.1 \mathrm{~Hz}, 12 \mathrm{H})$, $1.77(\mathrm{~m}, J=7.1 \mathrm{~Hz}, 12 \mathrm{H}), 2.62(\mathrm{t}, J=7.5 \mathrm{~Hz}, 12 \mathrm{H}), 4.24(\mathrm{t}$, $J=6.6 \mathrm{~Hz}, 12 \mathrm{H}), 6.26(\mathrm{~d}, J=8.1 \mathrm{~Hz}, 6 \mathrm{H}), 7.05(\mathrm{~s}, 6 \mathrm{H}), 7.25(\mathrm{~d}$, $J=8.4 \mathrm{~Hz}, 12 \mathrm{H}), 7.41(\mathrm{~d}, J=8.1 \mathrm{~Hz}, 12 \mathrm{H}), 7.46(\mathrm{t}, J=8.0 \mathrm{~Hz}$, $3 \mathrm{H}) ;{ }^{13} \mathrm{C}$ NMR $\left(75 \mathrm{MHz}, \mathrm{CDCl}_{3}\right): \delta=26.0,28.9,29.1,31.4$, 35.6, 66.0, 101.2, 126.5, 127.8, 128.9, 135.1, 140.9, 142.2, 163.0; ES-MS: $m / z=1367.1 \quad[\mathrm{M}+\mathrm{H}]^{+}$(calcd. for $\mathrm{C}_{93} \mathrm{H}_{111} \mathrm{~N}_{3} \mathrm{O}_{6}$ : 1366.86); anal. calcd. for $\mathrm{C}_{93} \mathrm{H}_{111} \mathrm{~N}_{3} \mathrm{O}_{6}$ : C 81.72, H 8.19; found: C 81.65, H 8.36.

\section{Macrocycle $6 \mathbf{f}$ \\ Cationic complex $4 \mathbf{f}(2.0 \mathrm{~g}, 0.73 \mathrm{mmol})$ and Grubbs' catalyst $\mathrm{Cl}_{2}\left(\mathrm{Cy}_{3} \mathrm{P}\right)_{2} \mathrm{Ru}=\mathrm{CHPh}(90 \mathrm{mg}, 0.109 \mathrm{mmol})$ were subsequently dissolved in dichloromethane $(750 \mathrm{~mL})$. The mixture was re- fluxed overnight under stirring, cooled to room temperature and concentrated under vacuum to $150 \mathrm{~mL}$. Saturated aqueous}

$\mathrm{NaCl}(40 \mathrm{~mL})$ was added and the mixture was stirred overnight. The organic layer was separated, dried $\left(\mathrm{MgSO}_{4}\right)$, filtered, and the solvents were evaporated. The RCM products were extracted with hexane, and separated by preparative TLC, eluent: dichloromethane/acetone $=15 / 1$. Yield: $0.37 \mathrm{~g}$ (44\%), colorless oil, which solidifies at room temperature. ${ }^{1} \mathrm{H}$ NMR $\left(200 \mathrm{MHz}, \mathrm{CDCl}_{3}\right): \delta=1.28(\mathrm{~m}, 60 \mathrm{H}), 1.64(\mathrm{~m}, J=$ $6.8 \mathrm{~Hz}, 12 \mathrm{H}), 1.97(\mathrm{~m}, 12 \mathrm{H}), 3.54(\mathrm{t}, J=6.4 \mathrm{~Hz}, 12 \mathrm{H}), 4.60(\mathrm{~s}$, $12 \mathrm{H}), 5.37(\mathrm{~m}, 6 \mathrm{H}), 7.33(\mathrm{~d}, J=7.7 \mathrm{~Hz}, 6 \mathrm{H}), 7.69(\mathrm{t}, J=$ $7.7 \mathrm{~Hz}, 3 \mathrm{H}) ;{ }^{13} \mathrm{C}$ NMR $\left(75 \mathrm{MHz}, \mathrm{CDCl}_{3}\right): \delta=26.2,29.1,29.5$, 29.5, 29.7, 29.8, 32.6, 71.3 , 73.8, 119.8, 130.5, 137.2, 158.4; ESMS: $m / z=1163.0[\mathrm{M}+\mathrm{H}]^{+}$(calcd. for $\mathrm{C}_{75} \mathrm{H}_{123} \mathrm{~N}_{3} \mathrm{O}_{6}: 1162.8$ ); anal. calcd. for $\mathrm{C}_{75} \mathrm{H}_{123} \mathrm{~N}_{3} \mathrm{O}_{6}$ : C 77.47, $\mathrm{H}$ 10.66, N 3.61; found: C 77.42, H 10.73, N 3.54.

\section{Macrocycle 7a}

Macrocycle 6a (500 mg, $0.463 \mathrm{mmol}$ ) was dissolved in dichloromethane $(15 \mathrm{~mL})$ and the palladium catalyst $(50 \mathrm{mg}, 10 \% \mathrm{Pd}$ on active coal) was added. The mixture was stirred under an atmosphere of hydrogen for $4 \mathrm{~h}$ at room temperature and filtered. The dichloromethane was evaporated under vacuum. Yield: $500 \mathrm{mg}$ (99\%), white solid. ${ }^{1} \mathrm{H}$ NMR (200 MHz, $\left.\mathrm{CDCl}_{3}\right): \delta=1.25(\mathrm{~m}, 84 \mathrm{H}), 1.75(\mathrm{~m}, J=6.8 \mathrm{~Hz}, 12 \mathrm{H}), 4.24(\mathrm{t}$, $J=6.8 \mathrm{~Hz}, 12 \mathrm{H}), 6.24(\mathrm{~d}, J=7.7 \mathrm{~Hz}, 6 \mathrm{H}), 7.44(\mathrm{t}, J=7.7 \mathrm{~Hz}$, $3 \mathrm{H}) ;{ }^{13} \mathrm{C}$ NMR $\left(75 \mathrm{MHz}, \mathrm{CDCl}_{3}\right): \delta=26.2,29.3,29.5,29.7$, 29.8, 66.1, 101.2, 140.9, 163.0; ES-MS: $m / z=1084.9[\mathrm{M}+\mathrm{H}]^{+}$ (calcd. for $\mathrm{C}_{69} \mathrm{H}_{111} \mathrm{~N}_{3} \mathrm{O}_{6}: 1084.7$ ); anal. calcd. for $\mathrm{C}_{69} \mathrm{H}_{117} \mathrm{~N}_{3} \mathrm{O}_{6}$ : C 76.40, H 10.87, N 3.87; found: C 76.30, H 10.81, N 3.79.

\section{Macrocycle 7d}

Macrocycle 6d (450 mg, $0.35 \mathrm{mmol}$ ) was dissolved in methanol $(20 \mathrm{~mL})$ and palladium on active coal $(10 \%, 50 \mathrm{mg})$ was added. The reaction mixture was stirred under hydrogen for $4 \mathrm{~h}$ and filtered. The solvent was evaporated under vacuum. Yield: $450 \mathrm{mg}$ (99\%), colorless oil. ${ }^{1} \mathrm{H}$ NMR $\left(300 \mathrm{MHz}, \mathrm{CDCl}_{3}\right): \delta=$ $1.62(\mathrm{~m}, J=2.9 \mathrm{~Hz}, 12 \mathrm{H}), 3.45(\mathrm{~m}, J=3.5 \mathrm{~Hz}, 12 \mathrm{H}), 3.54-$ $3.75(\mathrm{~m}, 48 \mathrm{H}), 3.82(\mathrm{t}, J=5.1 \mathrm{~Hz}, 12 \mathrm{H}), 4.41(\mathrm{t}, J=5.0 \mathrm{~Hz}$, $12 \mathrm{H}), 6.31(\mathrm{~d}, J=7.8 \mathrm{~Hz}, 6 \mathrm{H}), 7.45(\mathrm{t}, J=8.0 \mathrm{~Hz}, 3 \mathrm{H}) ;{ }^{13} \mathrm{C}$ NMR $\left(75 \mathrm{MHz}, \mathrm{CDCl}_{3}\right): \delta=26.4,65.2,69.8,70.2,70.8$, 70.9, 71.2, 101.9, 141.1, 162.4. ES-MS: $m / z=1288.75$ $[\mathrm{M}+\mathrm{H}]^{+}$(calcd. for $\mathrm{C}_{93} \mathrm{H}_{117} \mathrm{~N}_{3} \mathrm{O}_{6}: 1287.71$ ); anal. calcd. for $\mathrm{C}_{63} \mathrm{H}_{105} \mathrm{~N}_{3} \mathrm{O}_{24}$ : C 58.72, $\mathrm{H}$ 8.21, N 3.26; found: C 58.57, H 8.16, N 3.31 .

\section{Macrocycle 7e}

Macrocycle 6e $(70 \mathrm{mg}, 0.051 \mathrm{mmol})$ was dissolved in THF $(10 \mathrm{~mL})$ and palladium on active coal $(10 \%, 50 \mathrm{mg})$ was added. The reaction mixture was stirred under an atmosphere of hydrogen for five days and filtered. The solvent was evaporated under vacuum. Yield: $70 \mathrm{mg}(99 \%)$, colorless oil, which solidifies at room temperature. ${ }^{1} \mathrm{H}$ NMR $\left(300 \mathrm{MHz}, \mathrm{CDCl}_{3}\right): \delta=$ $1.30-1.46(\mathrm{~m}, 24 \mathrm{H}), 1.63(\mathrm{~m}, J=7.1 \mathrm{~Hz}, 12 \mathrm{H}), 1.76(\mathrm{~m}, J=$ $7.2 \mathrm{~Hz}, 12 \mathrm{H}), 2.59(\mathrm{t}, J=7.7 \mathrm{~Hz}, 12 \mathrm{H}), 2.86(\mathrm{~s}, 12 \mathrm{H}), 4.24(\mathrm{t}$, $J=6.8 \mathrm{~Hz}, 12 \mathrm{H}), 6.25(\mathrm{~d}, J=8.1 \mathrm{~Hz}, 6 \mathrm{H}), 7.08(\mathrm{~s}, 24 \mathrm{H}), 7.45$ $(\mathrm{t}, J=8.0 \mathrm{~Hz}, 3 \mathrm{H}) ;{ }^{13} \mathrm{C}$ NMR $\left(75 \mathrm{MHz}, \mathrm{CDCl}_{3}\right): \delta=26.1,29.1$, 29.2, 31.6, 35.6, 37.7, 66.0, 101.2, 128.44, 128.47, 139.3, 140.3, 140.9, 163.0; ES-MS: $m / z=1372.89[\mathrm{M}+\mathrm{H}]^{+}$(calcd. for 
$\mathrm{C}_{93} \mathrm{H}_{117} \mathrm{~N}_{3} \mathrm{O}_{6}$ : 1371.89); anal. calcd. for $\mathrm{C}_{93} \mathrm{H}_{117} \mathrm{~N}_{3} \mathrm{O}_{6}: \mathrm{C} 81.36, \mathrm{H}$ 8.59, N 3.06; found: C 81.25, H 8.46, N 3.14.

\section{Macrocycle 7f}

Macrocycle $6 \mathbf{f}$ (340 mg, $0.292 \mathrm{mmol}$ ) was dissolved in dichloromethane $(15 \mathrm{~mL})$ and palladium catalyst $(34 \mathrm{mg}, 10 \% \mathrm{Pd}$ on active coal) was added. The resulting mixture was stirred under an atmosphere of hydrogen for $4 \mathrm{~h}$ at room temperature and filtered after which the dichloromethane was evaporated under vacuum. The product was separated by preparative TLC, eluent: dichloromethane/acetone $=15 / 1$. Yield: $266 \mathrm{mg}$ (78\%), white solid. ${ }^{1} \mathrm{H}$ NMR $\left(200 \mathrm{MHz}, \mathrm{CDCl}_{3}\right): \delta=1.27$ (m, $84 \mathrm{H}), 1.63(\mathrm{~m}, J=6.8 \mathrm{~Hz}, 12 \mathrm{H}), 3.53(\mathrm{t}, J=6.4 \mathrm{~Hz}, 12 \mathrm{H}), 4.60$ $(\mathrm{s}, 12 \mathrm{H}), 7.33(\mathrm{~d}, J=7.7 \mathrm{~Hz}, 6 \mathrm{H}), 7.69(\mathrm{t}, J=7.7 \mathrm{~Hz}, 3 \mathrm{H}) ;{ }^{13} \mathrm{C}$ NMR $\left(75 \mathrm{MHz}, \mathrm{CDCl}_{3}\right): \delta=26.2,29.5,29.6,29.7,29.8,71.3$, 73.9, 119.9, 137.2, 158.4; ES-MS: $m / z=1169.2[\mathrm{M}+\mathrm{H}]^{+}$(calcd. for $\mathrm{C}_{75} \mathrm{H}_{129} \mathrm{~N}_{3} \mathrm{O}_{6}: 1168.8$ ); anal. calcd. for $\mathrm{C}_{75} \mathrm{H}_{129} \mathrm{~N}_{3} \mathrm{O}_{6}: \mathrm{C} 77.07$, H 11.12, N 3.60; found: C 77.05, H 11.21, N 3.49.

\section{Macrocycle 8}

Cationic complex $4 \mathbf{h}(2.6 \mathrm{~g}, 0.92 \mathrm{mmol})$ was dissolved in dichloromethane $(1000 \mathrm{~mL})$, and $\mathrm{Cl}_{2}\left(\mathrm{Cy}_{3} \mathrm{P}\right)_{2} \mathrm{Ru}=\mathrm{CHPh}$ (284 $\mathrm{mg}, 0.345 \mathrm{mmol}$ ) was added. The reaction mixture was stirred at reflux for $48 \mathrm{~h}$, cooled to room temperature, and the solution was concentrated to $1 / 3$ of the previous volume. A saturated aqueous solution of $\mathrm{NaCl}(50 \mathrm{~mL})$ was added and the reaction mixture was stirred overnight. The organic layer was separated, dried over $\mathrm{MgSO}_{4}$, and evaporated. The pyridine derivatives were extracted from the solid residue with hexane and further separated by preparative TLC. To recover the template precursor $\mathbf{3}$, the residue - after extraction with hexane - was washed with ethanol, dissolved in chloroform and filtered through silica. The chloroform was evaporated under vacuum to afford 3. Yield: $0.81 \mathrm{~g}(70 \%)$, light yellow oil. ${ }^{1} \mathrm{H}$ NMR $\left(200 \mathrm{MHz}, \mathrm{CDCl}_{3}\right): \delta=1.31(\mathrm{~m}, 20 \mathrm{H}), 1.78(\mathrm{~m}$, $J=6.8 \mathrm{~Hz}, 4 \mathrm{H}), 1.97(\mathrm{~m}, 4 \mathrm{H}), 4.40(\mathrm{~m}, 4 \mathrm{H}), 5.37(\mathrm{~m}, 2 \mathrm{H}), 8.77$ $(\mathrm{d}, J=2.0 \mathrm{~Hz}, 2 \mathrm{H}), 9.38(\mathrm{t}, J=2.0 \mathrm{~Hz}, 1 \mathrm{H}) ; \mathrm{GC} / \mathrm{MS}: \mathrm{m} / z=$ 416 (calcd. for $\mathrm{C}_{25} \mathrm{H}_{37} \mathrm{NO}_{4}$ : 415.6); anal. calcd. for $\mathrm{C}_{25} \mathrm{H}_{37} \mathrm{NO}_{4}$ : C 72.26, H 8.97, N 3.37; found: C 72.20, H 9.08, N, 3.45.

\section{Cationic Complex 9a}

Template precursor 3 (122 mg, $0.092 \mathrm{mmol}), \mathrm{AgBF}_{4}(54 \mathrm{mg}$, $0.276 \mathrm{mmol})$, and macrocycle $7 \mathbf{a}(100 \mathrm{mg}, 0.092 \mathrm{mmol})$ were mixed in dichloromethane $(20 \mathrm{~mL})$. The mixture was stirred overnight under the exclusion of light and filtered. The solvent was evaporated under vacuum. The crude product was dissolved in acetone $(10 \mathrm{~mL})$, and filtered, and the solvent was evaporated under vacuum. Yield: $226 \mathrm{mg}$ (95\%), white solid. ${ }^{1} \mathrm{H}$ NMR $\left(200 \mathrm{MHz}\right.$, acetone- $\left.d_{6}\right): \delta=1.04(\mathrm{~m}, 60 \mathrm{H}), 1.45(\mathrm{~m}$, $12 \mathrm{H}), 1.92(\mathrm{~m}, 24 \mathrm{H}), 2.98(\mathrm{~s}, 36 \mathrm{H}), 4.31(\mathrm{~s}, 12 \mathrm{H}), 4.41(\mathrm{~m}$, $12 \mathrm{H}), 6.95(\mathrm{~d}, J=8.0 \mathrm{~Hz}, 6 \mathrm{H}), 7.39(\mathrm{~s}, 6 \mathrm{H}), 7.82(\mathrm{~s}, 3 \mathrm{H}), 8.14$ $(\mathrm{t}, J=8.2 \mathrm{~Hz}, 3 \mathrm{H}) ;{ }^{13} \mathrm{C}$ NMR $\left(50 \mathrm{MHz}\right.$, acetone- $\left.d_{6}\right): \delta=27.1$, 29.6, 29.9, 30.0, 30.1, 30.2, 30.5, 54.4, 70.5, 77.8, 98.0, 101.3, 119.5, 124.2, 138.4, 144.2, 144.8, 145.4, 145.9, 164.0; ES-MS: $m / z=771.77$ (calcd. for $\mathrm{C}_{111} \mathrm{H}_{174} \mathrm{~N}_{9} \mathrm{O}_{6} \mathrm{Pt}_{3}{ }^{3+}:$ 771.75); anal. calcd. for $\mathrm{C}_{111} \mathrm{H}_{174} \mathrm{~B}_{3} \mathrm{~F}_{12} \mathrm{~N}_{9} \mathrm{O}_{6} \mathrm{Pt}_{3}$ : C 51.75, $\mathrm{H}$ 6.81, $\mathrm{N}$ 4.89; found: $\mathrm{C}$ $51.60, \mathrm{H} 6.74, \mathrm{~N}, 4.82$.

\section{Cationic Complex 9d}

Template precursor 3 (326 mg, $0.244 \mathrm{mmol}), \mathrm{AgBF}_{4}(143 \mathrm{mg}$, $0.733 \mathrm{mmol})$, and macrocycle $7 \mathbf{d}(315 \mathrm{mg}, 0.244 \mathrm{mmol})$ were mixed in dichloromethane $(10 \mathrm{~mL})$. The mixture was stirred overnight under the exclusion of light and filtered. The solvent was evaporated under vacuum. The crude product was dissolved in acetone $(10 \mathrm{~mL})$, filtered and evaporated under vacuum. Yield: $665 \mathrm{mg}(98 \%)$, white solid. ${ }^{1} \mathrm{H}$ NMR $(300 \mathrm{MHz}$, acetone- $\left.d_{6}\right): \delta=1.47(\mathrm{~m}, J=3 \mathrm{~Hz}, 12 \mathrm{H}), 3.04(\mathrm{~s}, 36 \mathrm{H}), 3.30$ $(\mathrm{m}, 12 \mathrm{H}), 3.36(\mathrm{~m}, 12 \mathrm{H}), 3.44(\mathrm{~m}, 12 \mathrm{H}), 3.59(\mathrm{~m}, 12 \mathrm{H}), 3.76$ $(\mathrm{m}, 12 \mathrm{H}), 4.03(\mathrm{~m}, 12 \mathrm{H}), 4.38(\mathrm{~s}, 12 \mathrm{H}), 4.54(\mathrm{~m}, 12 \mathrm{H}), 7.01(\mathrm{~d}$, $J=8.1 \mathrm{~Hz}, 6 \mathrm{H}), 7.45(\mathrm{~s}, 6 \mathrm{H}), 7.87(\mathrm{~s}, 3 \mathrm{H}), 8.18(\mathrm{t}, J=8.3 \mathrm{~Hz}$, $3 \mathrm{H}) ;{ }^{13} \mathrm{C}$ NMR $\left(75 \mathrm{MHz}\right.$, acetone- $\left.d_{6}\right): \delta=27.2,54.9,69.9$, 70.2, 70.6, 71.22, 71.29, 71.36, 71.44, 77.9, 101.5, 119.7, 124.3, 138.9, 142.9, 144.2, 146.2, 146.7, 163.9; ES-MS: $m / z=839.7$ (calcd. for $\mathrm{C}_{105} \mathrm{H}_{162} \mathrm{~N}_{9} \mathrm{O}_{24} \mathrm{Pt}_{3}{ }^{3+}$ : 839.7); anal. calcd. for $\mathrm{C}_{105} \mathrm{H}_{162} \mathrm{~B}_{3} \mathrm{~F}_{12} \mathrm{~N}_{9} \mathrm{O}_{24} \mathrm{Pt}_{3}$ : C 45.36, H 5.87, N 4.53; found: $\mathrm{C}$ 45.28, H 5.90, N 4.69.

\section{Cationic Complex 9f}

Template precursor $3(68.1 \mathrm{mg}, 0.051 \mathrm{mmol}), \mathrm{AgBF}_{4}(30 \mathrm{mg}$, $0.154 \mathrm{mmol})$ and macrocycle $7 \mathbf{f}(70 \mathrm{mg}, 0.051 \mathrm{mmol})$ were mixed in dichloromethane $(10 \mathrm{~mL})$. The mixture was stirred overnight under the exclusion of light and filtered. The solvent was evaporated under vacuum. The crude product was dissolved in acetone $(10 \mathrm{~mL})$, filtered, and the acetone was evaporated under vacuum. Yield: $145 \mathrm{mg}(99 \%)$, white solid. ${ }^{1} \mathrm{H}$ NMR $\left(300 \mathrm{MHz}\right.$, acetone- $\left.d_{6}\right): \delta=1.40(\mathrm{~m}, 12 \mathrm{H}), 1.58(\mathrm{~m}, J=$ $7.3 \mathrm{~Hz}, 12 \mathrm{H}), 1.91(\mathrm{~m}, 24 \mathrm{H}), 2.49(\mathrm{t}, J=7.4 \mathrm{~Hz}, 12 \mathrm{H}), 2.67(\mathrm{~s}$, $12 \mathrm{H}), 2.91(\mathrm{~s}, 36 \mathrm{H}), 4.23(\mathrm{~s}, 12 \mathrm{H}), 4.41(\mathrm{~s}, 12 \mathrm{H}), 6.71-6.86(\mathrm{~m}$, $24 \mathrm{H}), 6.94(\mathrm{~d}, J=8.4 \mathrm{~Hz}, 6 \mathrm{H}), 7.22(\mathrm{~s}, 6 \mathrm{H}), 7.77(\mathrm{~s}, 3 \mathrm{H}), 8.14$ $(\mathrm{t}, J=8.1 \mathrm{~Hz}, 3 \mathrm{H}) ;{ }^{13} \mathrm{C}$ NMR $\left(75 \mathrm{MHz}\right.$, acetone- $\left.d_{6}\right): \delta=27.2$, $31.8,35.3,38.0,54.4,70.4,77.8,101.3,119.9,124.8,128.9$, 129.2, 138.8, 139.7, 140.3, 144.4, 144.7, 145.4, 146.0, 164.1; ESMS: $m / z=868.2$ (calcd. for $\mathrm{C}_{135} \mathrm{H}_{174} \mathrm{~N}_{9} \mathrm{O}_{6} \mathrm{Pt}_{3}{ }^{3+}$ : 868.1); anal. calcd. for $\mathrm{C}_{135} \mathrm{H}_{174} \mathrm{~B}_{3} \mathrm{~F}_{12} \mathrm{~N}_{9} \mathrm{O}_{6} \mathrm{Pt}_{3}$ : C 56.60, H 6.12, N 4.40; found: C 56.47, H 6.06, N 4.29.

\section{Isomerized Pyridine 12}

Cationic 4a (0.382 g, $0.14 \mathrm{mmol})$ was dissolved in dry dichloromethane $(100 \mathrm{~mL})$ and Schrock catalyst 11 (0.016 g, $0.02 \mathrm{mmol}$ ) was dissolved in dry dichloromethane $(10 \mathrm{~mL})$ in a separate Schlenk tube. The solution of $\mathbf{1 1}$ was transferred via cannula into the solution of $\mathbf{4 a}$ and the flask rinsed with dichloromethane $(2 \times 1 \mathrm{~mL})$. The reaction mixture was heated to reflux for 16 hours after which the solvent volume was reduced to $40 \mathrm{~mL}$ and $\mathrm{NaCl}(1.30 \mathrm{~g})$ in water $(40 \mathrm{~mL})$ was added and the biphasic mixture was stirred in air overnight. The layers were separated and the aqueous layer washed with dichloromethane $(3 \times 40 \mathrm{~mL})$. The combined organics were dried over $\mathrm{MgSO}_{4}$, filtered and the solvent removed under vacuum. The product was extracted with hexanes $(3 \times 15 \mathrm{~mL})$ and the volatiles removed. The product was purified by preparative TLC, eluent: hexanes/dichloromethane $=7 / 3$. Yield $0.104 \mathrm{~g}(67 \%) .{ }^{1} \mathrm{H}$ NMR $\left(\mathrm{CDCl}_{3}, \quad 300 \mathrm{MHz}\right): \delta=0.86-0.98$ (overlapping t, $3 \mathrm{H}$, $\mathrm{CH}_{2} \mathrm{CH}_{3}$ ), 1.26-1.44 (br m, $10 \mathrm{H}, \mathrm{CH}_{2} \mathrm{CH}_{2} \mathrm{CH}_{2}$ ), 1.59 (d, $1 \mathrm{H}$, $\left.{ }^{3} J_{\mathrm{H}, \mathrm{H}}=5.7 \mathrm{~Hz},=\mathrm{CHCH}_{3}\right) 1.64(\mathrm{~m}, 3 \mathrm{H}), 1.76$ (overlapping $\mathrm{m}$, $5 \mathrm{H}, \mathrm{OCH}_{2} \mathrm{CH}_{2}$ and $\left.=\mathrm{CHCH}_{2} \mathrm{CH}_{2}\right), 1.97-2.04($ br m, $6 \mathrm{H}$, 
$\left.=\mathrm{CHCH}_{2}\right), 4.23\left(\mathrm{t}, 4 \mathrm{H},{ }^{3} J_{\mathrm{H}, \mathrm{H}}=6.8 \mathrm{~Hz}, \mathrm{OCH}_{2}\right), 4.95(\mathrm{~m}, 0.5 \mathrm{H}$, terminal $\left.=\mathrm{CH}_{2}\right), 5.35-5.44($ br m, $3.6 \mathrm{H}$, internal $=\mathrm{CH}), 5.82$ $(\mathrm{m}, 0.25 \mathrm{H}$, terminal $=\mathrm{CH}), 6.25\left(\mathrm{~d}, 2 \mathrm{H},{ }^{3} J_{\mathrm{H}, \mathrm{H}}=7.8 \mathrm{~Hz}, m\right.$ $\mathrm{ArH}), 7.45\left(\mathrm{t}, 1 \mathrm{H},{ }^{3} \mathrm{~J}_{\mathrm{H}, \mathrm{H}}=7.8 \mathrm{~Hz}, p-\mathrm{Ar} H\right) ;{ }^{13} \mathrm{C} \mathrm{NMR}\left(\mathrm{CDCl}_{3}\right.$, $75.5 \mathrm{MHz}): \delta=13.8,18.1\left(\mathrm{CH}_{3}\right), 25.8,26.1,26.3,\left(\mathrm{CH}_{2}\right), 28.8-$ 29.8 (10 signals, $\mathrm{OCH}_{2} \mathrm{CH}_{2},=\mathrm{CHCH}_{2} \mathrm{CH}_{2}$ ), 32.4-32.7 (5 signals, $\left.=\mathrm{CHCH}_{2}\right), 66.2\left(\mathrm{OCH}_{2}\right), 101.1(m-\mathrm{CH}), 114.3$ (terminal $\left.=C \mathrm{H}_{2}\right), 129.4-132.2(10$ signals, internal $=C \mathrm{H}), 139.4$ (terminal $=C \mathrm{H}), 140.9(p-C H), 163.1(\mathrm{OC}) ; \mathrm{GC} / \mathrm{MS}: m / z=388$.

\section{Crystal Structure Determination of Template Precursor 3}

The intensity data for a single crystal $(0.09 \times 0.24 \times 0.27 \mathrm{~mm})$ of 3 were collected using graphite-monochromated Mo- $K \alpha$ radiation, on a Nonius KappaCCD diffractometer at $150 \mathrm{~K}$. An empirical absorption correction was applied using PLATON/DELABS $\left(0.276-0.601\right.$ transmission range). ${ }^{[26 a]}$ The structure was solved by automated Patterson methods using DIRDIF99, ${ }^{[27]}$ and refined on $F^{2}$ using SHELXL97. ${ }^{[28]}$ The crystal structure

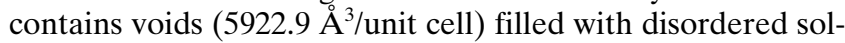
vent molecules (dichloromethane/ethanol). Their contribution to the structure factors was ascertained using PLATON/ SQUEEZE ${ }^{[266]}$ (1407 e/unit cell). All non-hydrogen atoms were refined with anisotropic displacement parameters. All hydrogen atoms were constrained to idealized geometries and allowed to ride on their carrier atoms with an isotropic displacement parameter related to the equivalent displacement parameter of their carrier atoms. Structure validation and molecular graphics preparation were performed with the PLATON package. ${ }^{[26 a]} \mathrm{C}_{42} \mathrm{H}_{57} \mathrm{Cl}_{3} \mathrm{~N}_{6} \mathrm{Pt}_{3}+$ solvate, trigonal, $\mathrm{R} \overline{3}$ (no. 148), $a=b=$ $22.6133(4), c=25.8840(6) \AA, V=11462.8(4) \AA^{3}, Z=6,2 \theta_{\max }=$ $55^{\circ}$. Of the 43247 reflections measured, 5861 were unique, 4754 with $\mathrm{I}>2 \sigma(\mathrm{I}), \mathrm{R}_{\mathrm{int}}=0.06, \mathrm{R}(\mathrm{F})[\mathrm{I}>2 \sigma(\mathrm{I})]=0.0355, \mathrm{wR}\left(\mathrm{F}^{2}\right)=$ $0.0858, \mathrm{~S}=1.04, \Delta \mathrm{r}_{\min } / \Delta \mathrm{r}_{\max }=-1.41 / 1.23 \mathrm{e}^{-3}$. CCDC 249318 contains the supplementary crystallographic data for this paper. These data can be obtained free of charge via www.ccdc. cam.ac.uk/conts/retrieving.html (or from the CCDC, 12 Union Road, Cambridge CB2 1EZ, UK; fax: +44 1223 336033; e-mail: deposit@ccdc.cam.ac.uk).

\section{Crystal Structure Analysis of $\left[7 \mathrm{a}\left(\mathrm{BPh}_{4}\right)_{3}\right] \mathbf{1 0}$}

$\left[\mathbf{7 a}\left(\mathrm{BPh}_{4}\right)_{3}\right] \mathbf{1 0}$ was obtained by an exchange reaction from $\left[7 \mathbf{a}\left(\mathrm{BF}_{4}\right)_{3}\right] 9$ and $\mathrm{NaBPh}_{4}$ in acetone. Colorless plates were obtained after recrystallization in acetone/ $\mathrm{Et}_{2} \mathrm{O}$. Intensity data were collected for a single crystal $(0.27 \times 0.15 \times 0.06 \mathrm{~mm})$ on a Nonius KappaCCD diffractometer with rotating anode (Mo K $\alpha, \lambda=0.71073 \AA$ ) at $150 \mathrm{~K}$, to a maximum resolution of $2 \theta_{\max }=55^{\circ}$. Of the 109149 reflections measured, 38222 were unique, 24201 with $\mathrm{I}>2 \sigma(\mathrm{I})\left(\mathrm{R}_{\mathrm{int}}=0.058\right)$. An absorption correction was applied using the multi-scan technique with PLATON/MULABS $\left(\mu=2.548 \mathrm{~mm}^{-1}, 0.705-0.856\right.$ transmission range). ${ }^{[26 a]}$ The structure was solved by automated Patterson methods using DIRDIF99, ${ }^{[27]}$ and refined on $\mathrm{F}^{2}$ by leastsquares procedures using SHELXL97. ${ }^{[28]}$ Structure validation and molecular graphics preparation were performed with the PLATON package.[26 ${ }^{\mathrm{b}}$ ] $\mathrm{C}_{111} \mathrm{H}_{174} \mathrm{~N}_{9} \mathrm{O}_{6} \mathrm{Pt}_{3} \cdot 3\left(\mathrm{C}_{24} \mathrm{H}_{20} \mathrm{~B}\right), M_{r}=$ 3273.49, triclinic, $\mathrm{P} \overline{1}$ (no. 2), $a=18.9296(1), b=20.6363(1)$, $c=22.4100(2) \quad \AA, \quad \alpha=80.4058(3), \quad \beta=86.3821(3), \quad \gamma=$
76.7954(3) $)^{\circ}, V=8400.66(10) \AA^{3}, Z=2, \rho_{\text {calcd. }}=1.294 \mathrm{~g} \cdot \mathrm{cm}^{-3}$; 2219 refined parameters, 3563 restraints, $\mathrm{R}(\mathrm{F})[\mathrm{I}>2 \sigma(\mathrm{I})]=$ $0.0517, \quad w R\left(F^{2}\right)=0.1357, \quad \mathrm{~S}=1.04, \quad \Delta \mathrm{r}_{\max } / \Delta \mathrm{r}_{\min }=1.92 /-1.49$ e $\AA^{-3}$. CCDC 185367 contains the supplementary crystallographic data for this paper, see above for access.

The asymmetric unit in $\mathbf{1 0}$ contains one independent cationic complex and three independent tetraphenylborate anions, as well as disordered solvent molecules (acetone $/ \mathrm{Et}_{2} \mathrm{O}$ ) that could not be resolved in the difference Fourier map. The solvent contribution was treated using PLATON/SQUEEZE (58 e/unit cell). ${ }^{[26 a]}$ The three macrocycle bridges of the cation are each disordered over two sets of atomic positions [with refined occupancies of $0.536(7): 0.464,0.63(1): 0.37$, and 0.630(7):0.370, respectively]. The NCN-pincer moiety coordinated to $\operatorname{Pt}(2)$ is also disordered over two conformations at different twist angles relative to the central benzene ring [with refined occupancies of $0.655(6): 0.345]$. All non-hydrogen atoms were refined with anisotropic displacement parameters, but the displacement parameters of the disordered atoms were restrained to be approximately isotropic. Hydrogen atoms were constrained to idealized geometries and allowed to ride on their carrier atoms with an isotropic displacement parameter related to the equivalent displacement parameter of their carrier atoms.

\section{Acknowledgements}

This research was supported in part (A.V.C.) by the Netherlands Research School Combination Catalysis (NRSC-C), (P. A.C.) the Natural Sciences and Engineering Research Council of Canada (NSERC), and (H. P. D., A. M. M. and A. L. S.) by the Council for Chemical Sciences of the Netherlands Organisation for Scientific Research (CW-NWO).

\section{References and Notes}

[1] a) E. C. Constable, Coordination Chemistry of Macrocyclic Compounds, Academic, San Diego, CA, 1999; b) L. F. Lindoy, The Chemistry of Macrocyclic Ligand Complexes, Cambridge University Press, Cambridge, UK, 1992.

[2] a) P. L. Anelli, N. Spencer, J. F. Stoddart, J. Am. Chem. Soc. 1991, 113, 5131-5133; b) R. A. Bissell, E. Cordova, A. E. Kaifer, J. F. Stoddart, Nature 1994, 369, 133-137; c) J. O. Jeppesen, J. Perkins, J. Becher, J. F. Stoddart, $A n$ gew. Chem. Int. Ed. 2001, 40, 1216-1221.

[3] C. P. Collier, G. Mattersteig, E. W. Wong, Y. Luo, K. Beverly, J. Sampaio, F. M. Raymo, J. F. Stoddart, J. R. Heath, Science 2000, 289, 1172-1175.

[4] C. P. Collier, E. W. Wong, M. Belohradsky, F. M. Raymo, J. F. Stoddart, P. J. Kuekes, R. S. Williams, J. R. Heath, Science 1999, 285, 391-394.

[5] a) D. B. Amabilino, J. F. Stoddart, Chem. Rev. 1995, 95, 2725-2829; b) F. M. Raymo, J. F. Stoddart, Chem. Rev. 1999, 99, 1643-1663; c) A. R. Pease, J. O. Jeppesen, J. F. Stoddart, Y. Luo, C. P. Collier, J. R. Heath, Acc. Chem. Res. 2001, 34, 433-444.

[6] a) J. A. Harnisch, R. J. Angelici, Inorg. Chim. Acta 2000, 300-302, 273-279; b) H. L. Anderson, J. K. M. Sanders, 
J. Chem. Soc. Perkin Trans. 1. 1995, 29, 2223-2229 and references cited therein.

[7] a) H. P. Dijkstra, M. D. Meijer, J. Patel, R. Kreiter, G. P. M. van Klink, M. Lutz, A. L. Spek, A. J. Canty, G. van Koten, Organometallics 2001，20， 3159-3168; b) H. P. Dijkstra, C. A. Kruithof, N. Ronde, R. van de Coevering, D. J. Ramon, D. Vogt, G. P. M. van Klink, G. van Koten, J. Org. Chem. 2003, 68, 675-685; c) I. P. Beletskaya, A. V. Chuchuryukin, H. P. Dijkstra, G. P. M. van Klink, G. van Koten, Tetrahedron Lett. 2000, 41, 1081-1085.

[8] a) R. R. Schrock, A. H. Hoveyda, Angew. Chem. Int. Ed. 2003, 42, 4592-4633; b) H. E. Blackwell, D. J. O'Leary, A. K. Chatterjee, R. A. Washenfelder, D. A. Bussmann, R. H. Grubbs, J. Am. Chem. Soc. 2000, 122, 58-71; c) T. M. Trnka, R. H. Grubbs, Acc. Chem. Res. 2001, 34, 18-29; d) P. Schwab, M. B. France, J. W. Ziller, R. H. Grubbs, Angew. Chem. Int. Ed. 1995, 34, 2039-2041; e) Handbook of Metathesis (Ed.: R. H. Grubbs), WileyVCH, Weinheim, 2003

[9] a) E. B. Bauer, J. Ruwwe, F. A. Hampel, S. Szafert, J. A. Gladysz, J. M. Martín-Alvarez, T. B. Peters, J. C. Bohling, T. Lis, Chem. Commun. 2000, 2261-2262 and references cited therein; b) T. Shima, F. Hampel, J. A. Gladysz, Angew. Chem. Int. Ed. 2004, 43, 5537-5540.

[10] M. Weck, B. Mohr, J.-P. Sauvage, R. H. Grubbs, J. Org. Chem. 1999, 64, 5463-5471.

[11] G. Rapenne, C. Dietrich-Buchecker, J.-P. Sauvage, J. Am. Chem. Soc. 1999, 121, 994-1001.

[12] J. Stahl, J. C. Bohling, E. B. Bauer, T. B. Peters, W. Mohr, J. M. Martín-Alvarez, F. Hampel, J. A. Gladysz, Angew. Chem. Int. Ed. 2002, 41, 1872-1876.

[13] H. P. Dijkstra， A. Chuchuryukin， B. M. J. M. Suijkerbuijk, G. P. M. van Klink, A. M. Mills, A. L. Spek, G. van Koten, Adv. Synth. Catal. 2002, 344, 771-780.

[14] C. W. Bird, Transition Metal Intermediates in Organic Synthesis, Academic Press: New York 1967, 69.

[15] a) A. V. Chuchuryukin, H. P. Dijkstra, B. M. J. M. Suijkerbuijk, R. J. M. Klein Gebbink, G. P. M. van Klink, A. M. Mills, A. L. Spek, G. van Koten, Angew. Chem. Int. Ed. 2003, 42, 228-230; b) A. V. Chuchuryukin, H. P. Dijkstra， B. M. J. M. Suijkerbuijk， R. J. M. Klein Gebbink, G. P. M. van Klink, A. M. Mills, A. L. Spek, G. van Koten, Russ. J. Org. Chem. 2003, 39, 422-429.

[16] A. Fürstner, A. Leitner, Angew. Chem. Int. Ed. 2003, 42, 308-311.

[17] Use of $\mathrm{PtO}_{2}{ }^{[17 \mathrm{a}]}$ as hydrogenation catalyst or of a nitrogen-containing base as inhibitor for the side reaction ${ }^{[17 \mathrm{~b}]}$ might increase the yield of $\mathbf{7 f}$; a) $\mathrm{H}$. Pettersson-Fasth, S. W. Riesinger, J. E. Bäckvall, J. Org. Chem. 1995, 60, 6091-6096; b) H. Sajiki, K. Hirota, Tetrahedron 1998, 54, 13981-13996.

[18] K. J. Ivin, J. C. Mol, Olefin Metathesis and Metathesis Polymerization, Academic Press, San Diego, CA, 1997.

[19] Grubbs' first-generation catalyst: a) S. J. Miller, H. E. Blackwell, R. H. Grubbs, J. Am. Chem. Soc. 1996, 118, 9606-9614; b) T. R. Hoye, H. Zhao, Org. Lett. 1999, 1, 169-171; c) T. R. Hoye, H. Zhao, Org. Lett. 1999, 1, $1123-1125$.

[20] Grubbs' second-generation catalyst: a) S. S. Kinderman, J. H. van Maarseveen, H. E. Shoemaker, H. Hiemstra, F. P. J. T. Rutjes, Org. Lett. 2001, 3, 2045-2048; b) J. Wagner, L. M. Martin Cabrejas, C. E. Grossmith, C. Papageorgiou, F. Senia, D. Wagner, J. France, S. P. Nolan, J. Org. Chem. 2000, 65, 9255-9260; c) A. Fürstner, O. R. Thiel, L. Ackermann, H.-J. Schanz, S. P. Nolan, J. Org. Chem. 2000, 65, 2204-2207; d) J. Huang, E. D. Stevens, S. P. Nolan, J. L. Peterson, J. Am. Chem. Soc. 1999, 121, 2674-2678; e) M. Scholl, T. M. Trnka, J. P. Morgan, R. H. Grubbs, Tetrahedron Lett. 1999, 40, 2247-2250; f) D. Bourgeois, A. Pancrazi, S. P. Nolan, J. Prunet, J. Organometal. Chem. 2002, 643-644, 247-252.

[21] S. E. Lehman, J. E Schwendeman, P. M. O'Donnell, K. B. Wagener, Inorg. Chem. Acta. 2002, 345, 190-198.

[22] E. Thorn-Csányi, J. Dehmel, H.-D. Luginsland, J. U. Zilles, J. Mol. Cat. A, 1997, 115, 29-35.

[23] D. Joe, L. E. Overman, Tetrahedron Lett. 1997, 38, 86358638.

[24] For an example on photoswitchable dendritic hosts, see: A. Archut, G. C. Azzellini, V. Balzani, L. De Cola, F. Vögtle, J. Am. Chem. Soc. 1998, 120, 12187-12191.

[25] For an example of an 68-membered, 20 O-containing host with multiple (4) cations, see: P. R. Ashton, M. C. T. Fyfe, P. T. Glink, S. Menzer, J. F. Stoddart, A. J. P. White, D. J. Williams, J. Am. Chem. Soc. 1997, $119,12514-12524$.

[26] a) A. L. Spek, J. Appl. Cryst. 2003, 36, 7-13; b) P. van der Sluis, A. L. Spek, Acta Cryst. 1990, A46, 194-201.

[27] P. T. Beurskens, G. Admiraal, G. Beurskens, W. P. Bosman, S. García-Granda, R. O. Gould, J. M. M. Smits, C.Smykalla, The DIRDIF99 Program System; Technical Report of the Crystallography Laboratory, University of Nijmegen, The Netherlands, 1999.

[28] G. M. Sheldrick, SHELXL97, University of Göttingen, Germany, 1997. 